\title{
Evaluation of Hydroxyapatite crystallization in a batch reactor for the valorization of alkaline phosphate concentrates from wastewater treatment plants using calcium chloride
}

\author{
M. Hermassi ${ }^{\mathrm{a}, \mathrm{b}}$, C. Valderrama ${ }^{\mathrm{a},{ }^{,},}$, J. Dosta ${ }^{\mathrm{c}}$, J.L. Cortina ${ }^{\mathrm{a}}$, N.H. Batis ${ }^{\mathrm{b}}$ \\ ${ }^{a}$ Chemical Engineering Department. Universitat Politècnica de Catalunya-Barcelona TECH. \\ ${ }^{b}$ Department of Biological and Chemical Engineering, National Institute of Applied Sciences \\ and Technology (INSAT), University of Carthage (Tunisia) \\ ${ }^{\mathrm{c}}$ Department of Chemical Engineering, Universitat de Barcelona (UB), Barcelona (Spain) \\ *Correspondence should be addressed to: César Valderrama \\ Departament d'Enginyeria Química, Universitat Politècnica de Catalunya \\ Av. Diagonal 647, 08028, Barcelona Spain \\ Tel.: 93 4011818, Fax.: 934015814 \\ Email: cesar.alberto.valderrama@upc.edu
}

\section{Abstract}

In this work, phosphorous recovery as hydroxyapatite $\left(\mathrm{Ca}_{5}\left(\mathrm{PO}_{4}\right)_{3} \mathrm{OH}(\mathrm{s})=\mathrm{Hap}\right)$ from alkaline phosphate concentrates $\left(0.25\right.$ to $\left.1 \mathrm{~g} \mathrm{P}-\mathrm{PO}_{4}^{3-} / \mathrm{L}\right)$ using calcium chloride $(6 \mathrm{~g} / \mathrm{L})$ in a batch reactor was evaluated. $\mathrm{Ca}(\mathrm{II})$ solutions was continuously fed $(0.1-0.3 \mathrm{~mL} / \mathrm{min})$ up to reaching a $\mathrm{Ca} / \mathrm{P}$ ratio of $\sim 1.67(5 / 3)$ to promote Hap formation. Hap powders were characterized by structural form (using X-ray diffraction (XRD), laser light scattering (LS) and Fourier transform infrared spectroscopy (FTIR)); textural form (using Field Emission Scanning Electron Microscopy with Energy Dispersive System (FE-SEM/EDS) and Brunauer-EmmettTeller (BET)) and thermally (using Thermogravimetric Analysis (TGA)/Differential Thermal Analysis (DTA)). When $\mathrm{pH}$ was kept constant in alkaline values (from 8 to 11.5), Hap precipitation efficiency was improved. At $\mathrm{pH}$ 11.5, higher phosphorous precipitation rate was registered compared to that obtained for $\mathrm{pH} 8$ and 10, but lower degree of crystallinity was 
observed in the Hap powders. The increase of the total initial phosphate concentration lead to the formation of Hap powders with higher degree of crystallinity and crystal diameter, but also lower mean particle size. As $\mathrm{Ca}(\mathrm{II})$ dosing rate increased Hap precipitation rate was higher, and also the mean size and degree of crystallinity of the prepared particles increased.

Keywords: $\mathrm{P}(\mathrm{V})$ recovery; Hap precipitation; batch reactor; crystallization; $\mathrm{CaCl}_{2}$; solid characterization.

\section{Introduction}

Phosphorus management has been recently highlighted by the United Nations Environment Program as one of the main emerging problems to be faced in the next decades. The use of phosphorous needs to become more efficient and its recycling more widespread, since the demand for phosphorus is increasing and the available phosphorous resources are scarce. For instance, the excessive phosphorus content in wastewaters should be removed for controlling eutrophication and maintaining a sustainable environment for future generations. Several physical, biological and chemical processes include adsorption/ ion exchange, chemical precipitation/coagulation, crystallization and membrane filtration/ reverse osmosis for the removal and / or recovery of dissolved phosphates $(\mathrm{P}(\mathrm{V}))$ in water and wastewaters have been investigated $[1,2,3]$.

Different research efforts during the last decade, have probed that phosphorus recovery at low levels (e.g. 2-10 mg/L), from domestic and urban waste waters is not economically feasible, using conventional removal processes (coagulation, chemical precipitation, adsorption, ionexchange) $[2,4,5]$. However, the introduction of new processes using P-selective sorbents (e.g. metal oxides sorbents or metal oxide impregnated ion exchange resins) will provide

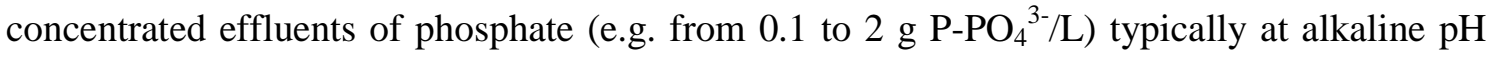
values (9 to 12) due to the requirements of the regeneration step using 2 to $5 \% \mathrm{NaOH}$ 
52 solutions [6]. The alkaline $\mathrm{P}(\mathrm{V})$-brines are suitable candidates to recover the phosphate 53 content as (calcium, magnesium, ammonium)-phosphate by-products using $\mathrm{Ca}$ (II), $\mathrm{Mg}(\mathrm{II})$,

$54 \mathrm{NH}_{4}{ }^{+}$brines generated in many industrial effluents, especially in processes using membrane 55 desalination technologies or using low-cost raw materials $[1,7,8]$.

56 In alkaline solutions, calcium phosphates (Ca-P) are highly stable minerals [9] however 57 involve the crystallization of many metastable precursor phases. Amorphous calcium 58 phosphate $\left(\mathrm{ACP}, \mathrm{Ca} / \mathrm{P}(1.5), \mathrm{Ca}_{3}\left(\mathrm{PO}_{4}\right)_{2} \cdot \mathrm{nH}_{2} \mathrm{O}\right)$, dicalcium phosphate dihydrate (DCPD, $59 \mathrm{Ca} / \mathrm{P}(1), \mathrm{CaHPO}_{4} \cdot 2 \mathrm{H}_{2} \mathrm{O}$, brushite), $\beta$-whitlockite $\left(\beta-\mathrm{TCP}, \mathrm{Ca} / \mathrm{P}(1.5), \quad \beta-\mathrm{Ca}_{3}\left(\mathrm{PO}_{4}\right)_{2}\right)$ and 60 octacalcium phosphate $\left(\mathrm{OCP}, \mathrm{Ca} / \mathrm{P}(1.33) \mathrm{Ca}_{8} \mathrm{H}_{2}\left(\mathrm{PO}_{4}\right)_{6} .5 \mathrm{H}_{2} \mathrm{O}\right)$. All of them are frequently 61 precipitated at low $\mathrm{pH}$ values. Hydroxyapatite (Hap) $\left(\mathrm{Ca} / \mathrm{P}(1.67), \mathrm{Ca}_{5}\left(\mathrm{PO}_{4}\right)_{3} \mathrm{OH}\right)$ is the less 62 soluble phase, preferentially formed in neutral to basic solutions [10,11]. Hap, is a compound with a variable composition existing over $\mathrm{Ca} / \mathrm{P}$ molar ratios from 1.67 for stoichiometric up to $\approx 1.5$ for fully calcium-deficient Hap [12], and sometimes even outside this range [13]. Direct precipitation of Hap has only been observed for low reactants concentrations, that is, slightly supersaturated or under saturated aqueous solutions with respect to a precursor phase $[14,15]$.

67 Thermodynamically, Hap is postulated to control the $\mathrm{PO}_{4}{ }^{3-}$ concentration in many natural and 68 industrial aqueous streams; however, the remaining $\mathrm{P}(\mathrm{V})$ concentration appear to be controlled for lengthy periods by meta-stable phases [9].

Hap synthesis by a precipitation route stands out because of its simplicity, low cost, and easy application in industrial production [16,17], although other methods are also used. Different procedures and starting salts have been used as source of phosphate $(\mathrm{P}(\mathrm{V}))$ and $\mathrm{Ca}(\mathrm{II})$ ions. Boskey and Posner [15], Lagno et al. [10], and more recently Du et al. [18] formed Hap by adding a $\mathrm{CaCl}_{2}$ solution of ( $\mathrm{pH}$ 7.4-7.6) to a solution of $\mathrm{Na}_{2} \mathrm{HPO}_{4}(\mathrm{pH} 10-11)$, or vice versa at 
76 Koutsoukos et al. [19] also studied the precipitation of Hap at $37^{\circ} \mathrm{C}$. Recently, Castro et al.

77 [17] prepared Hap in a batch reactor by neutralization between a saturated $\mathrm{Ca}(\mathrm{OH})_{2}$ solution with orthophosphoric acid solution, using several mixing $\mathrm{Ca} / \mathrm{P}$ molar ratios (namely, 1, 1.33 and 1.67$)$ at $37^{\circ} \mathrm{C}$ and a agitation speed of $270 \mathrm{rpm}$.

Continuous Stirred-Tank Reactor (CSTR), Plug Flow Reactor (PFR) and Batch Reactors (BR) have been set up to study phosphate crystallization. Some researchers have demonstrated that BR have the advantage of providing extreme flexibility of operation and at the same time being physically simple, since all the treatment operations (i.e. flow equalization, precipitation reactions and solids settling) take place in one single tank. Castro et al. [20] also studied the continuous flow precipitation of Hap performed in a meso oscillatory flow reactor at laboratory and pilot-scale at $37^{\circ} \mathrm{C}$, at a molar ratio $\mathrm{Ca} / \mathrm{P}$ of 1.33 .

Phosphorous recovery is a topic of great concern nowadays and Hap precipitation has been reported as a suitable process to recover phosphate in a BR, thus, the integration of different technologies (sorption/ion exchange-precipitation) in a waste water treatment scheme can provide an alternative solution for phosphorous recovery. In view of that, the main objective of this work was to assess the recovery of phosphate $\mathrm{P}(\mathrm{V})$ from alkaline brines by using $\mathrm{Ca}$ (II) solution to precipitate Hap under different experimental conditions in a BR. The alkaline brines were obtained from a $\mathrm{P}(\mathrm{V})$ concentration process from waste water using ironoxide impregnated ion-exchange resins. The Hap precipitation process was evaluated as a function of $\mathrm{pH}$, as well as the $\mathrm{Ca}(\mathrm{II})$ dosing rate, the stirring speed and phosphate initial concentration. The Hap precipitates obtained under these operation conditions were properly characterized through the degree of crystallinity, the crystal diameter, the particle size distribution and the thermal analysis.

\section{Materials and Methods}




\subsection{Experimental set-up and procedures}

101 The precipitation of phosphate from aqueous solutions was performed in a two liters lab-scale

102 batch reactor made of glass as can be seen in Figure 1. Agitation in the reactor was provided

103 by a mechanical stirrer (IKA RW 20 and Heidolph RZR) and the stirring speed was ranged 104 from 50 to $250 \mathrm{rpm}$. $\mathrm{pH}$ was monitored in-line by using a $\mathrm{pH}$ potentiometer (Crison $\mathrm{pH} 28$ ).

105 When $\mathrm{pH}$ was 0.1 units above or below the set point, strong acid ( $\mathrm{HCl} 1 \mathrm{M})$ or strong base $106(\mathrm{NaOH} 1 \mathrm{M})$ were dosed using a peristaltic pump (Master flex console drive). Experiments 107 batch tests were carried out mixing a volume of $\mathrm{NaH}_{2} \mathrm{PO}_{4}$ solution (with an initial phosphate 108 concentration between 0.25 to $\left.1.0 \mathrm{~g} P-\mathrm{PO}_{4}^{3-} / \mathrm{L}\right)$ with a $\mathrm{CaCl}_{2}$ solution $(6.0 \mathrm{~g} \mathrm{Ca}(\mathrm{II}) / \mathrm{L})$ 109 added at a flow rate $\left(\mathrm{Q}_{\mathrm{Ca}}\right)$ between 0.1 and $0.3 \mathrm{ml} / \mathrm{min}$ (by means of a peristaltic pump Gilson 110 Minipuls 3). The reaction time was ranged between 6 and 24 hours depending on the initial 111 phosphate concentration, the flow rate and in order to reach at the end of the test a molar ratio $112 \mathrm{Ca} / \mathrm{P}$ of 1.67 , suitable for Hap precipitation. Experiments were performed at room 113 temperature. Three different types of experiments were performed: i) experiments to study the 114 influence of $\mathrm{pH}$ (at 8,10 and 11.5$)$ at constant initial phosphate concentration $\left(1.0 \mathrm{~g} \mathrm{P}-\mathrm{PO}_{4}{ }^{3-}\right.$ $115 \mathrm{~L})$, calcium dosing rate $(0.1 \mathrm{~mL} / \mathrm{min})$ and stirring speed $(250 \mathrm{rpm})$; ii) experiments to study 116 the influence of the total initial phosphate $(\mathrm{P}(\mathrm{V}))$ concentration $(0.25,0.375,0.5$ and $1.0 \mathrm{~g} / \mathrm{L})$ 117 at constant $\mathrm{pH}(11.5)$, calcium dosing rate $(0.1 \mathrm{ml} / \mathrm{min})$ and the stirring speed $(250 \mathrm{rpm})$, iii) 118 experiments to study the influence of the stirring speed (50,100, 150 and $250 \mathrm{rpm}$ ) and 119 calcium dosing rate (at $0.1,0.2$ and $0.3 \mathrm{ml} / \mathrm{min}$ ) at constant $\mathrm{pH}(11.5)$ and total initial 120 phosphate concentration $\left(1.0 \mathrm{~g} \mathrm{P}-\mathrm{PO}_{4}^{3-} / \mathrm{L}\right)$.

122 Batch reactor aqueous samples were taken along the experiments and filtered through $0.45 \mathrm{um}$ 123 filter. The total concentrations of the $\mathrm{Ca}(\mathrm{II})$ and $\mathrm{P}(\mathrm{V})$ were measured by Ion Chromatography 
using an Ionex Liquid Chromatography (ICS-1000). The accuracy of the measurements was higher than $95 \%$.

After the conclusion of the experiments, the precipitated solids of the batch reactor were filtered, washed with water several times and dried at $\mathrm{T}=60^{\circ} \mathrm{C}$ during $24 \mathrm{~h}$. The samples were metalized with gold and then were examined using a JEOL 3400 Field Emission Scanning Electron Microscopy with Energy Dispersive System (FE-SEM-EDS). Samples were also analyzed by Fourier transform infrared spectroscopy (FTIR), in the range $4000 \mathrm{~cm}^{-1}-500 \mathrm{~cm}^{-1}$, (JASCO, FT/IR-4100).

\subsubsection{Particle size analysis}

Particle size distribution of the Ca-P powder precipitates was analyzed by laser light scattering (LS) with a Coulter diffract particle size analyzer (LS 13320 Laser Diffraction Particle Size Analyzer Instrument, Beckman Coulter). The size crystal distribution range (CSD) detected was from 0.04 to $2000 \mu \mathrm{m}$. The particle size expressed as both volume and number distributions, allows to detect the presence of aggregates and also to assess the size of the majority of the particles, respectively. Particles were analyzed as obtained directly from the batch reactor without any thermal treatment and granulometric separation.

\subsubsection{Thermogravimetric Analysis (TGA) and Differential Thermal Analysis (DTA)}

Thermogravimetric analyses were carried out in a Mettler TGA/SDTA 851e thermo balance. Dried samples with an approximate mass of $8 \mathrm{mg}$ were degraded between 30 and $800{ }^{\circ} \mathrm{C}$ at a heating rate of $10{ }^{\circ} \mathrm{C} / \mathrm{min}$ in $\mathrm{N}_{2}\left(100 \mathrm{~cm}^{3} / \mathrm{min}\right.$ measured in normal conditions $)$ atmosphere. The precision of reported temperatures was estimated to be $\pm 2{ }^{\circ} \mathrm{C}$.

\subsubsection{BET analysis}


146 The specific surface area $\left(\mathrm{S}_{\mathrm{BET}}\right)$ of the powders was measured using multipoint Brunauer-

147 Emmett-Teller (BET) method at low temperature using Micrometrics Flow Sorb II 2300. The 148 equivalent particle diameter $\left(\mathrm{d}_{\mathrm{BET}}\right)$ was calculated from the measured surface area $\left(\mathrm{S}_{\mathrm{BET}}\right)$ 149 values by using Eq. 1 [21].

$150 \quad \mathrm{~d}_{\mathrm{BET}}=\frac{6}{\rho S_{B E T}}$

151 where $\rho$ is the theoretical density of Hap $\left(3.167 \mathrm{~g} / \mathrm{cm}^{3}\right)$.

$152 \quad$ 2.1.4 X-ray diffraction (XRD) analysis

153 The phase purity and crystallinity of the Hap powder were analyzed by X-ray diffraction with $154 \lambda \mathrm{CuK \alpha} \alpha$ radiation $(\lambda=1.54056 \AA))$ at a scanning rate time of 19.2 and $57.6 \mathrm{~s}$, steep angle of $1550.015^{\circ}$ and $2 \theta$ in range of $4-60^{\circ}$. The average crystallite size long c-direction of Hap powder 156 was calculated from (002) reflection in XRD pattern, using Sherrer's equation (Eq. 2) [22]:

$$
\tau=\frac{K \lambda}{\beta \cos \theta}
$$

where $\tau(\mathrm{nm})$ is crystallite size, $\mathrm{K}$ is the shape factor $(\mathrm{K}=0.9), \lambda$ is the wavelength of the $\mathrm{X}$ ray $(\lambda=0,15406 \mathrm{~nm}$ for $\mathrm{CuK} \alpha$ radiation), $\beta$ is the full width at half- maximum (FWHM) (rad) of the peak along (002) direction and $\theta$ is the Bragg's diffraction angle.

161 The crystallinity degree (Xc) was determined using Eq. 3:

$$
X c=(0.24 / \beta)^{3} \cdot 100 \%
$$
Diffraction Standards (JCPDS) file and it was matched with Powder Diffraction File (PDF) no. 00-009-0432 for Hap. 
167 Precipitation processes were designed using the HYDRA-MEDUSA code [23]. Measured $168 \mathrm{P}(\mathrm{V})$ and $\mathrm{Ca}(\mathrm{II})$ concentrations were compared when necessary with those predicted by using 169 HYDRA-MEDUSA code. The effect of ionic strength on single salt solubility and formation 170 of pure precipitates was taken into account in the calculations. Aqueous species and mineral 171 phases of the $\mathrm{CaCl}_{2}-\mathrm{NaH}_{2} \mathrm{PO}_{4}-\mathrm{H}_{2} \mathrm{O}$ system considered on the calculations are detailed in 172 Table 1.

\section{Table 1.}

$174 \mathrm{Ca}(\mathrm{II})$ and phosphate ions could forms different $\mathrm{Ca}-\mathrm{P}$ mineral phases (e.g. $\left.\mathrm{Ca}_{\left(\mathrm{H}_{2}\right.} \mathrm{PO}_{4}\right)_{2}$,

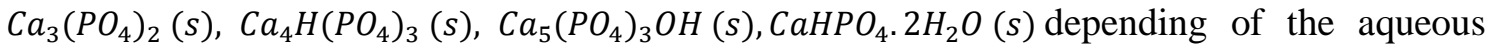
phase composition and the concentrations of the specie involved. The species distribution diagram as a function of $\mathrm{pH}$ simulating the conditions of the precipitation assays in three scenarios are shown in Figure 2 a, b and c, respectively: a) excess of $\mathrm{P}(\mathrm{V})$ over $\mathrm{Ca}(\mathrm{II})$ (molar ratio of 200) simulating the initial step of the precipitation assays; b) an slightly excess of $\mathrm{P}(\mathrm{V})$ over $\mathrm{Ca}(\mathrm{II})$ (molar ratio of 10 ) simulating the conditions approaching to the stoichiometric molar ratio, and c) an excess of $\mathrm{Ca}(\mathrm{II})$ over $\mathrm{P}(\mathrm{V})$ (molar ratio 0.5) simulating the final steps of the precipitation trials. As it can be seen the $\mathrm{pH}$ and the levels of concentration of both calcium and phosphate, are influencing the aqueous chemistry and then the precipitation of Ca-P minerals. For a mixture of $10 \mathrm{mM}$ of $\mathrm{PO}_{4}{ }^{3-}$ with $50 \mu \mathrm{M}$ of $\mathrm{Ca}^{2+}$ 185 (Figure 2a) the excess of $\mathrm{PO}_{4}^{3--}$ and $\mathrm{H}_{2} \mathrm{PO}_{4}^{-}$ions promotes the formation of complexes as $186 \mathrm{CaPO}_{4}{ }^{-}$and $\mathrm{CaH}_{2} \mathrm{PO}_{4}$ and it is expected the partial precipitation of $\mathrm{Ca}_{3}\left(\mathrm{PO}_{4}\right)_{2(\mathrm{~S})}$ above $\mathrm{pH} 8$. 187 The increase of $\mathrm{pH}$ above $\mathrm{pH} 10$ favors the formation of the complex $\mathrm{CaPO}_{4}{ }^{-}$in solution.

188 The reduction of the excess of $\mathrm{P}(\mathrm{V})$ to $\mathrm{Ca}(\mathrm{II})$ for $10 \mathrm{mM}$ of $\mathrm{PO}_{4}{ }^{3-}$ and $1 \mathrm{mM}$ of $\mathrm{Ca}$ (II), (Figure 
from $\mathrm{pH}$ values above 6 for a $\mathrm{Ca} / \mathrm{P}$ ratio of 1.67 and above 5 for solutions with an excess of $\mathrm{Ca}(\mathrm{II})$. This is also accompanied by a reduction the $\mathrm{CaH}_{2} \mathrm{PO}_{4}^{+}$and $\mathrm{CaHPO}_{4}$ molar fractions.

\section{Figure 2.}

\section{Results and Discussion}

\subsection{Effect of pH in Hap precipitation}

The influence of the $\mathrm{pH}$ in the precipitation of $\mathrm{P}(\mathrm{V})$ along the experiment for two experiments one at constant $\mathrm{pH}$ at 11.5 and other with an initial $\mathrm{pH}$ solution at 10.5 (variable $\mathrm{pH}$ ) as well as the evolution of calcium concentration along the experiment is shown in Figures $3 \mathrm{a}$ and $3 \mathrm{~b}$.

The evolution of $\mathrm{pH}$ along the experiment, shown in Figure $3 \mathrm{c}$, follows three differentiate stages. After the initial additions of calcium (up to $0.5 \mathrm{mM} \mathrm{Ca(II))} \mathrm{the} \mathrm{pH}$ of solution is kept constant between 10.5 to 10.7 taking benefit of the buffer capacity of the initial solution $\left(\mathrm{HPO}_{4}{ }^{-2} / \mathrm{H}_{2} \mathrm{PO}_{4}\right)$. The evolution of the total $\mathrm{P}(\mathrm{V})$ concentration shows an strong reduction (30\% of the initial concentration) as a function of the addition of $\mathrm{Ca}(\mathrm{II})(3.6 \mathrm{mmol} / \mathrm{L})$ and then it is stabilized around after $240 \mathrm{~min}$, corresponding to the addition of $5.4 \mathrm{mmol} / \mathrm{l}$ of $\mathrm{Ca}(\mathrm{II})$. As it is shown in Figure 2a the predominant $\mathrm{P}(\mathrm{V})$ species in solution between $\mathrm{pH} 10$ and 12 is $\mathrm{CaPO}_{4}^{-}$. Under this conditions it has been postulated a shift on the surface charge of the mineral leading to the precipitation of amorphous calcium phosphate [24], $\mathrm{Ca}_{3}\left(\mathrm{PO}_{4}\right)_{2}$ or $\beta$-whitlockite $\left(\beta-\mathrm{Ca}_{3}\left(\mathrm{PO}_{4}\right)_{2}\right)[25]$ as it is described by Eq. 4 .

$$
3 \mathrm{CaPO}_{4}^{-}+\mathrm{H}^{+} \rightarrow \mathrm{Ca}_{3}\left(\mathrm{PO}_{4}\right)_{2(s)}+\mathrm{HPO}_{4}^{2-}
$$

\section{Figure 3.}

Although potentially such phase can be formed it was not detected at the end of the precipitation test and only Hap, was detected by XRD analysis. 
212 The addition of $\mathrm{Ca}(\mathrm{II})$ is traduced into slightly decrease of $\mathrm{P}(\mathrm{V})$ concentration as it is

213 observed in Figure 2b, and an increase of the total $\mathrm{Ca}(\mathrm{II})$ concentration in solution as can be

214 seen in Figure 3a. Subsequently the $\mathrm{pH}$ decreased with a S-shape form due to the reduction of

215 the $\mathrm{HPO}_{4}^{2-}$ concentration by formation of Hap (Figure 3c). After this abroad change the $\mathrm{pH}$ of

216 the solution diminished slowly as it is reached the $\mathrm{H}_{2} \mathrm{PO}_{4}^{-} / \mathrm{HPO}_{4}^{2-}$ buffer $(\mathrm{pKa} 2=7.2)$.

217 During this second stage, $\mathrm{pH}$ decreased from 10 to 7.4 and phosphate ions $\mathrm{P}(\mathrm{V})$ were present

218 in solution mainly as $\mathrm{CaHPO}_{4}$ (see Figure 2a) and the precipitation of Ca-P could be 219 described by reaction Eq. 5 .

$2205 \mathrm{CaHPO}_{4(a q)}+\mathrm{H}_{2} \mathrm{O} \leftrightarrow \mathrm{Ca}_{5}\left(\mathrm{PO}_{4}\right)_{3}(\mathrm{OH})_{(s)}+2 \mathrm{HPO}_{4}^{2-}+4 \mathrm{H}^{+}$

221 The addition of $\mathrm{Ca}(\mathrm{II})$ is traduced in a small decrease of $\mathrm{pH}$ during the last stage indicating 222 the growing of formed Hap. Although an excess of $\mathrm{Ca}(\mathrm{II})$ was added the removal of 223 phosphate from solution only reached a $50 \%$.

224 On the other hand, in the experiment with constant $\mathrm{pH}(11.5 \pm 0.1)$ the phosphate profile 225 shows a continuous decrease with the addition of $\mathrm{Ca}$ (II) reaching a removal of phosphate 226 higher than $96 \%( \pm 2 \%)$ (Figure 3a). At the end of the experiment the precipitated solid was 227 identified as Hap as described latter. The levels of total $\mathrm{Ca}(\mathrm{II})$ concentration in solution were 228 below of $20 \mathrm{mmol} / \mathrm{L}$. These values were two orders of magnitude higher than those predicted 229 assuming that the system was equilibrated with Hap, which indicates that the system did not 230 reach equilibrium.

231 The evolution of phosphate $((\mathrm{P}(\mathrm{V}))$ concentration and recovery as a function of calcium 232 concentration at constant $\mathrm{pH}$ values $(8,10$ and 11.5) are shown in Figure 4. 
234 It can be seen (Figure 4b) that precipitation /crystallization of Hap can be divided in three 235 well-defined stages for experiments at constant $\mathrm{pH}$ of 10 and 11.5 and just two stages for $\mathrm{pH}$ 2368 . In the stage 1 (stage 1 ), induction period, early nucleation took place and a reduced amount 237 of phosphate was removed during the first $30 \mathrm{~min}(0.36 \mathrm{mmol} \mathrm{Ca}(\mathrm{II}) / \mathrm{L})$. The maximum $\mathrm{P}(\mathrm{V})$ removal ratios were observed for $\mathrm{pH} 10$ and 11.5 (11 and $6 \%$, respectively). This initial step 239 in alkaline $\mathrm{pH}$ conditions has been described by reaction Eq. $6[26,17,24]$ :

$$
3 \mathrm{Ca}^{2+}+2 \mathrm{HPO}_{4}^{2-} \leftrightarrow \mathrm{Ca}_{3}\left(\mathrm{PO}_{4}\right)_{2(s)}+2 \mathrm{H}^{+}
$$

241 Han et al. [24] identified at $\mathrm{pH}$ 10, the precipitation of an amorphous calcium phosphate 242 (ACP) phase at the initial reaction time and then it crystallized into Hap after $2 \mathrm{~h}$ of reaction. 243 In the second stage (stage 2), the homogenous nucleation of Hap occurred (from 30 to 180 244 min equivalent to $1.8 \mathrm{mmol} \mathrm{Ca}(\mathrm{II}) / \mathrm{L})$. During the nucleation stage, the total concentration of $245 \mathrm{Ca}(\mathrm{II})$ remained constant to $0.80 \pm 0.2 \mathrm{mmol} \mathrm{Ca}(\mathrm{II}) / \mathrm{L}$ and the $\mathrm{P}(\mathrm{V})$ removal increased from 2 to $10 \%$ for $\mathrm{pH} 10$ and from 5 to $20 \%$ for $\mathrm{pH} 11.5$ (Figure 4). In the final stage (stage 3), 247 further homogeneous nucleation bulk precipitation of Hap was observed, until reaching a final $\mathrm{P}(\mathrm{V})$ removal efficiency of $81 \%$ and $95 \%$, for $\mathrm{pH} 10$ and 11.5 , respectively. Analysis at the end of the experiment of solid samples by XRD analysis determined the presence of Hap. 250 Values of $\mathrm{Ca}(\mathrm{II})$ concentration measured along the experiments were higher than those 251 predicting equilibrium with the formation of Hap, indicating a kinetic control, however at the end of the experiment under excess of $\mathrm{Ca}(\mathrm{II})$ the measured and calculated values were in agreement.

At $\mathrm{pH} 8$, the two stages observed were the precipitation of Hap, with a phosphate removal ratio up to $20 \%$, followed by a homogeneous nucleation stage of Hap with a phosphate removal ratio up to $78 \%$. This is in agreement with results reported in literature at $\mathrm{pH} 7.5$ in 257 which Hap phase was directly observed immediately the reaction was started [26]. 
259

260

261

262

263

264

265

266

267

268

269

270

271

272

273

274

275

276

277

278

279

280
The evolution of total $\mathrm{P}(\mathrm{V})$ concentration phosphate profiles for experiments carried out at constant $\mathrm{pH}(11.5 \pm 0.2)$ for initial phosphate concentrations of $0.25,0.375,0.5$ and $1.0 \mathrm{~g} \mathrm{P}-$ $\mathrm{PO}_{4}^{3-} / \mathrm{L}$ are shown in Figure 5. The total $\mathrm{P}(\mathrm{V})$ concentration decreased with the addition of $\mathrm{Ca}$ (II) reaching a final concentration below $0.2 \mathrm{mg} \mathrm{P}-\mathrm{PO}_{4}^{3-} / \mathrm{L}$ (limit of quantification for $(\mathrm{P}(\mathrm{V}))$ in this study), which stands for more than $65 \%$ of $\mathrm{P}(\mathrm{V})$ removal as Hap as it was determined by XRD analysis. Total Ca(II) concentrations in solutions were below the limit of quantification, for the lower $\mathrm{P}(\mathrm{V})$ concentrations and below $1 \mathrm{mmol} / \mathrm{L}$ for the concentrated experiment $(1.0 \mathrm{~g} / \mathrm{L})$, indicating a total phosphate removal (> 99\% ) as a Hap with a $\mathrm{Ca} / \mathrm{P}$ ratio of 1.67 , approximately.

\section{Figure 5}

The kinetics of precipitation of Hap is important in explaining the oversaturation of aqueous phase with respect to initial phosphate and calcium concentration. Consequently, several empirical equations have been used to describe the kinetics of Hap based on driving forces calculated from disequilibrium [19,27]. Inskeep and Silvetooh [28] determined the rate reaction order with respect to solution or surface area and determined that the rate of Hap at pH 7.4 to 8.4 could be expressed by Eq. 7 as follow:

$R=K_{f} \cdot \gamma\left(\mathrm{Ca}^{2+}\right) \cdot \gamma\left(\mathrm{PO}_{4}^{3-}\right) \mathrm{S}\left[\mathrm{Ca}^{2+}\right]\left[\mathrm{PO}_{4}^{3-}\right]$

where $\mathrm{R}$ is the rate of Hap precipitation (mol Hap/ $\mathrm{L} \cdot \mathrm{s}), \mathrm{k}_{\mathrm{f}}$ is the rate constant $\left(\mathrm{L}^{2} / \mathrm{mol} \cdot \mathrm{m}^{2} \mathrm{~s}\right)$, $\gamma\left(\mathrm{Ca}^{2+}\right)$ and, $\gamma\left(\mathrm{PO}_{4}^{3-}\right)$ are the divalent and trivalent ion activity coefficients, respectively, $\mathrm{s}$ is the surface area $\left(\mathrm{m}^{2} / \mathrm{g}\right)$, and $\left[\mathrm{Ca}^{+2}\right]$ and $\left[\mathrm{PO}_{4}{ }^{-3}\right]$ are the molar concentrations of $\mathrm{Ca}^{+2}$ and $\mathrm{PO}_{4}^{-3}(\mathrm{~mol} / \mathrm{L})$ 
281 As it could be seen in Figure 5, for each experiment at a given concentration, the $\mathrm{Ca}$ (II) 282 concentration was below $0.05 \mathrm{mmol} / \mathrm{L}$ (the detection limit in this study) for 0.25 and $0.375 \mathrm{~g}$ $283 \mathrm{P}-\mathrm{PO}_{4}{ }^{-3} / \mathrm{L} ; 0.15 \mathrm{mmol} / \mathrm{L}$ for $0.5 \mathrm{~g} \mathrm{P}^{-\mathrm{PO}_{4}}{ }^{-3} / \mathrm{L}$ and $0.7 \mathrm{mmol} / \mathrm{L}$ for $1.0 \mathrm{~g} \mathrm{P}-\mathrm{PO}_{4}{ }^{-3} / \mathrm{L}$. 284 Additionally the surface area of the precipitated Hap, in each experiment, ranged from 67 $285 \mathrm{~g} / \mathrm{m}^{2}$ up to $90 \mathrm{~g} / \mathrm{m}^{2}$ as the initial concentration increases. Then, assuming that for each 286 experiment at a given concentration the values of $\mathrm{k}_{\mathrm{F}} \gamma\left(\mathrm{Ca}^{+2}\right), \gamma\left(\mathrm{PO}_{4}^{-3}\right), \mathrm{S}$ and $\left[\mathrm{Ca}^{+2}\right]$ are 287 constant, the precipitation rate equation could be simplified to Eq. 10:

$R=-\left(\frac{1 d\left[\mathrm{PO}_{4}^{3-}\right]}{3 d t}\right)=k_{f} \cdot \gamma\left(\mathrm{Ca}^{2+}\right) \cdot \gamma\left(\mathrm{PO}_{4}^{3-}\right) \mathrm{S}\left[\mathrm{Ca}^{2+}\right]\left[\mathrm{PO}_{4}^{3-}\right]=\mathrm{k}_{\mathrm{f}}^{\prime}\left[\mathrm{PO}_{4}^{3-}\right]$ and integrating Eq. 10 between a given $t$, with $[\mathrm{P}(\mathrm{V})]$ and time $\mathrm{t}=0$ for $[\mathrm{P}(\mathrm{V})]_{0}$ it could be 290 obtained:

$291 \operatorname{Ln} \frac{\left[\mathrm{PO}_{4}^{3-}\right]}{\left[\mathrm{PO}_{4}^{3-}\right]_{0}}=-k_{f}^{\prime} t$

where $\mathrm{t}$ is time $(\mathrm{s})$, and $\mathrm{k}_{\mathrm{f}}^{\prime}=k_{f} \cdot \gamma\left(\mathrm{Ca}^{2+}\right) \cdot \gamma\left(\mathrm{PO}_{4}^{3-}\right) \mathrm{S}\left[\mathrm{Ca}^{2+}\right]$

293 The evolution of the $\operatorname{Ln} \frac{\left[\mathrm{PO}_{4}^{3-}\right]}{\left[\mathrm{PO}_{4}^{3-}\right]_{0}}$ as a function of time (Figure 6) follows a linear dependence 294 for each $[\mathrm{P}(\mathrm{V})]$ concentration. The slopes of these functions were used to calculate the 295 precipitation rate constants $\mathrm{k}_{\mathrm{f}}^{\prime}$ at $\mathrm{pH} 11.5$ (Table 2). The decrease of $\mathrm{P}(\mathrm{V})$ concentration from 296 1.0 to $0.25 \mathrm{P}_{-} \mathrm{PO}_{4}{ }^{-3} \mathrm{~g} / \mathrm{L}$ is traduced in an increase of the $\mathrm{k}_{\mathrm{f}}^{\prime}$ constant up to 2.5 times. It indicates that the rate of Hap precipitation follows the proposed first order rate with respect to $\mathrm{Ca}^{2+}, \mathrm{PO}_{4}^{3--}$, and surface area $[28,16]$.

Table 2.

\section{Figure 6.}




\subsection{Influence of stirring and $\mathrm{Ca}(\mathrm{II})$ addition rate}

304 Phosphate precipitation experiments under different stirring speeds in the range $50 \mathrm{rpm}$ up to $305250 \mathrm{rpm}$ were carried out. The phosphate concentration evolution did not show any significant 306 influence on the $\mathrm{P}(\mathrm{V})$ recovery ratio as it can be seen in Figure $7 \mathrm{a}$, and indicating the absence 307 of mass transfer phenomena limitations. The percentage of $\mathrm{P}(\mathrm{V})$ recovery was always above $30895 \pm 3 \%$.

309 On the other hand, the increase of $\mathrm{Ca}$ (II) dosing addition up to $0.3 \mathrm{~mL} / \mathrm{min}$, was traduced in 310 the increase of the phosphate removal ratio above 99\% (Figure $7 b$ ) and the phosphate 311 precipitation rate was slightly higher than for lower dossing ratios as was described 312 previously by Xie et al. [29].

\subsection{Precipitate Characterization}

The nature of the solids and crystals formed were characterized by XRD (diffraction patterns

317 are shown in Figure 8 and summarized in Tables 3 and 4). A single phase Hap powder is

318 shown in Figure 8, according to the reference Hap (see Table 3), was obtained in the different experiments (e.g. constant and variable $\mathrm{pH}$ and also at different initial phosphate concentration). The strongest peak intensity of the Hap samples at $2 \theta=31.87^{\circ}$ was of the

321 (211) crystal plan and the other peak at $2 \theta=25.87^{\circ}$ corresponds to the (002) crystal plane.

322 Besides, the other characteristic peaks with less intensity were of the (112) and (300) crystal 323 plane. 
324 It is important to point out that 211 and 002 reflection intensities showed an increased trend

325 by increasing solution phosphate concentration as is shown in Figure 8, which indicates that 326 maturation in Hap crystallinity took place with time.

327 In fact, the degree of crystallinity or the fraction of the crystalline phase $X_{c}$ for the

328 hydroxyapatites obtained through different initial phosphate concentration can be evaluated 329 by using equation 3 .

Figure 8.

\section{Table 3.}

Table 4.

Main functional groups of the different powder Hap samples were confirmed by FTIR analysis (data not shown). It was detected the presence of characteristic bands around $600 \mathrm{~cm}^{-}$

$335{ }^{1}$ corresponding to $v 4\left(\mathrm{OPO}, \mathrm{PO}_{4}^{3-}\right)$ bending mode. Also the $960 \mathrm{~cm}^{-1}$ band was assigned to $v 1$ 336 (PO) symmetric stretching and a band in the range $1100-1000 \mathrm{~cm}^{-1}$ was assigned to $v 3$ (PO, $337 \mathrm{PO}_{4}^{3-}$ ) antisymmetric stretching mode. The small band around $875 \mathrm{~cm}^{-1}$ can be attributed to 338 the vibrational frequencies of carbonate ions or $\mathrm{HPO}_{4}^{2-}$ group [30]. Furthermore, the 339 carbonate peaks in the range $1500-1400$ and $868 \mathrm{~cm}^{-1}$, corresponding to the asymmetric 340 stretching ( $v 3$ mode) and out of plane bending ( $v 2$ mode) vibrations, respectively $[31,32,33]$ 341 were identified. Presence of these bands is characteristic of a carbonate Hap of B-type, where 342 the carbonate ions occupy the phosphate ions sites [30,34]. The formation of carbonate could 343 be due to the adsorption of atmospheric $\mathrm{CO}_{2}$ during the ripening time, due to the highly 344 alkaline conditions in the solution $[31,33,35]$. 
347 The Hap crystal diameters (calculated by Eq. 2) showed that the powders prepared are mostly 348 constituted by nanoparticles as it is summarized in Table 4. The crystal diameter increased 349 with decreasing de $\mathrm{pH}$ of the crystallization process, namely from $22 \mathrm{~nm}(\mathrm{pH} \mathrm{11.5)}$ to around $35030 \mathrm{~nm}(\mathrm{pH}$ 8). Moreover, the crystal diameter and the degree of crystallinity were similar for $351 \mathrm{pH}$ values of 10 and 8 and presented the lower values. The experiment at variable $\mathrm{pH}$ reported 352 similar nanometric powder sizes and crystallinity than those obtained for constant $\mathrm{pH}$ at 11.5.

353 Also, the stirring speed affected the degree of crystallinity, with, $83 \%$ at $150 \mathrm{rpm}$, and ranged 354 between and around 20 to $27 \%$ for 75 and $250 \mathrm{rpm}$. The increase of the $\mathrm{Ca}$ (II) dosing flow355 rate (from 0.1 to $0.3 \mathrm{ml} / \mathrm{min}$ ) revealed an slight increase of both crystal size and crystallinity 356 degree (from 22 to $27 \mathrm{~nm}$, and from 27 to $50 \%$, respectively).

357 For experiments under different phosphate concentrations, the highest degree of crystallinity $358(27 \%)$ and crystal diameter $(22 \mathrm{~nm})$ were obtained when the maximum initial $\mathrm{P}(\mathrm{V})$ 359 concentration was used $\left(1.0 \mathrm{~g} \mathrm{P}-\mathrm{PO}_{4}^{3-} / \mathrm{L}\right)$. These findings can be explained by the process of 360 Figure 9.

362 Additionally, and according to Figure 9, the granulometric analysis of precipitated particles in volume of particles (Figure 9a) revealed the formation of aggregates with an average 364 equivalent diameter around $57 \mu \mathrm{m}$ for variable $\mathrm{pH}$ and from 8.8 to $70 \mu \mathrm{m}$ for constant $\mathrm{pH}$ 365 (11.5 to 8). From the particle size laser analysis in number (Figure 9b), the crystals obtained with Hap precipitation with not constant $\mathrm{pH}$ ranged in size from 0.063 to $0.405 \mu \mathrm{m}$ and have a mean equivalent diameter of $0.112 \mu \mathrm{m}$, presenting a narrow size distribution curve, similar to those obtained with constant $\mathrm{pH}(0.107 \mu \mathrm{m})$. From the particle size distribution in number of particles, it is observed that powders prepared were mostly constituted by nanoparticles. 
370 This enormous decrease variation of the average diameter in the aggregates and the constant

371 crystal mean size $\left(\mathrm{d}_{50}\right)$ with an increase at constant $\mathrm{pH}$, it is attributed to some degree of

372 heterogeneous nucleation as well as to an aggregation process in the nanometric scale. This

373 aggregation process reduces the number of small crystals [36]. Results also show that the

374 mean size and the aggregation degree of the precipitated particles increased with increasing of

375 the calcium flowrate dosing. As stated in Table 4, Hap particles with a mean size $\left(\mathrm{d}_{50}\right)$ of 89

$376 \mathrm{~nm}$ were obtained at calcium flowrates of 0.1 and $0.2 \mathrm{ml} / \mathrm{min}$. For $0.3 \mathrm{ml} / \mathrm{min}, \mathrm{d}_{50}$ was $431 \mathrm{~nm}$

377 and in large aggregates of about $587 \mu \mathrm{m}$. Therefore, it was observed that as the $\mathrm{Ca}(\mathrm{II})$ dosing

378 flow-rate was higher, the aggregation phenomenon was more pronounced. Xie et al. [29]

379 described this behaviour and observed that when $\mathrm{Ca}(\mathrm{II})$ is added rapidly, the high local super-

380 saturation will affect the dehydratation process and it will influence ions association and the

381 nucleation behavior. On the other hand, the increased $\mathrm{d}_{50}$ number through the increase of the

382 flowrate contributes to a distribution of supersaturation in the reaction environment, thereby

383 leading to uniform distribution of the driving force for the nucleation and growth processes

384 and give rise to a narrow size distribution [37].

385 The influence of the initial phosphate concentration on the mean particle size of Hap 386 nanoparticles is shown in Figure $9(\mathrm{c}-\mathrm{d})$. The results indicate that the mean particle size $\left(\mathrm{d}_{50}\right)$ 387 decreased with the increase of the initial $\mathrm{P}(\mathrm{V})$ concentration. The decrease of particle size was $388494,332,92$ and $89 \mathrm{~nm}$ for $0.25,0.375,0.5$ and $1.0 \mathrm{~g} \mathrm{P}-\mathrm{PO}_{4}^{3-} / \mathrm{L}$, respectively. Therefore, for 389 initial $\mathrm{P}(\mathrm{V})$ concentrations above $0.5 \mathrm{~g} \mathrm{P}-\mathrm{PO}_{4}^{3-} / \mathrm{L}$, Hap particles with size around $90 \mathrm{~nm}$ were 390 obtained. This it is attributed to the fact that the increase of initial $\mathrm{P}(\mathrm{V})$ concentration led to a 391 high supersaturation level, which made nucleation and growth very fast, thereby resulting in 392 the generation of small particles as described previously [37,38]. However, a large amount of 393 Hap primary nuclei were spontaneously formed when the concentration reached a rather high 
value. In this case, the aggregation of Hap primary nuclei was greatly intensified during the reaction, causing the poly-dispersity of Hap nanoparticles as described by Yang et al. [37].

From large scale application point of view, the settling velocity was accounted by using the Stokes law. This law describes the dependency of unhindered terminal particle settling velocities on the basis of their diameters and densities under laminar flow condition.

If Hap is stimulated to precipitate, the crystal formed must reach a certain minimum size to enable them to acquire enough downward velocity to naturally settle to the base of a typical clarifier tank for collection. Thus, according to the Stokes law for particle settling, the average settling was determined to be $0.005 \mathrm{~m} / \mathrm{s}$, this value was constant for experiments at different stirring speed and also for those at initial phosphate concentration above $500 \mathrm{mg} \mathrm{P}-\mathrm{PO}_{4} / \mathrm{L}$.

In addition, Table 4 reports the specific surface area $\left(\mathrm{S}_{\mathrm{BET}}\right)$ estimated from the specific area $\left(\mathrm{d}_{\mathrm{BET}}\right)$ methodology. An increase in specific surface area of Hap was observed as $\mathrm{pH}$ was increased from 8 to 11.5 . Moreover, at constant $\mathrm{pH}$ of $11.5, \mathrm{~S}_{\mathrm{BET}}$ increased with increasing initial $\mathrm{P}(\mathrm{V})$ concentration. Thus, the increase of surface area represents an increase of the powder reactivity for crystal growth.

The specific surface area obtained for experiment at variable $\mathrm{pH}$ (initial $\mathrm{pH}$ of 11.5) was in the range of $60 \mathrm{~m}^{2} / \mathrm{g}$, but with at constant $\mathrm{pH}$ (initial $\mathrm{pH}=11.5$ ) was incremented to $90 \mathrm{~m}^{2} / \mathrm{g}$. The stirring speed and calcium dosing rate (at $\mathrm{pH} 11.5$ ) did not significantly affect the specific surface area.

The EDS analysis indicated that the samples were predominantly composed of $\mathrm{Ca}, \mathrm{P}$ and $\mathrm{O}$, the major elements of Hap powders. The SEM/EDS micrographs of the powders obtained from various initial phosphate concentrations, at variable or constant $\mathrm{pH}$ are shown in Figure 10. The powders consisted of rod like shape and plate-shaped nanometric sized particles. As it 
417 can be seen from the particles morphology, there is a distribution of small particles and large agglomerates (consisting of fine cold welded particles).

\section{Figure 10.}

420

421

422

426

427

428

429

430

431

432

434

435

436

437

A higher tendency to form aggregates was observed with higher initial phosphate concentration and at constant $\mathrm{pH}$ (Figure 10b). More nearly monodisperse plate shaped with a length of about $1 \mu \mathrm{m}-100 \mathrm{~nm}$ was found for initial phosphate concentration above $0.5 \mathrm{~g} \mathrm{P}$ $\mathrm{PO}_{4}^{3-} / \mathrm{L}$. This is in accordance with the results reported by Dirksen and Ring [39] who described the appearance of different growth morphologies with the existence of concentration gradients at the crystal surface, which lead to growth instabilities and the formation of dendrites (Figure 10a and b).

Besides, the powders obtained in batch tests with variable and constant $\mathrm{pH}$ ( at initial phosphate concentration of $\left.1.0 \mathrm{~g} \mathrm{P}-\mathrm{PO}_{4}^{3-} / \mathrm{L}\right)$ showed a morphology of plate-shaped or rodshaped (Figure 10b-c) with a size around $100 \mathrm{~nm}$. Powders presented a certain degree of aggregation, which can be justified by the amorphous nature of the particles (degree of crystallinity around 27 and $39 \%$ for constant and variable $\mathrm{pH}$, respectively (Table 4)).

\subsection{Thermal characterization}

In the thermogram analysis, Hap crystals were characterized by a continuous mass loss throughout the increase of temperature. Hap crystals with low degree of crystallinity (Test number 2) reported three thermal transitions of mass loss in the temperature region (Figure 11). The first one is of $8 \%$ at $560^{\circ} \mathrm{C} \geq \mathrm{T} \geq \mathrm{T}_{\text {room }}$ corresponding from physic-sorbed and surface absorbed water molecule. The second mass loss of $2.5 \%$ (between 560 and $830{ }^{\circ} \mathrm{C}$ ) can be attributed firstly to the loss of water present in the lattice structure (the so-called strongly related intra-crystalline water) and secondly to the decomposition of phosphate ions 
$440\left(300-500{ }^{\circ} \mathrm{C}\right)[3]$ and corresponding to the early stages of crystallization. The third mass loss 441 occurs at temperatures higher than $830{ }^{\circ} \mathrm{C}$, in which Hap will dehydrate partially to form the 442 oxy-hydroxyapatite according to Eq. 12 [40]:

$$
\mathrm{Ca}_{10}\left(\mathrm{PO}_{4}\right)_{6} \mathrm{OH}_{2(s)} \rightarrow \mathrm{Ca}_{10}\left(\mathrm{PO}_{4}\right)_{6} \mathrm{OH}_{2-2 x} \mathrm{O}_{x(s)}+x \mathrm{H}_{2} \mathrm{O}_{(g)}
$$

444 The thermogram obtained for Hap samples with high degree Hap crystallinity (Test number 445 8) presented just two thermal transitions in the temperature region. The first one, from room 446 temperature to $830{ }^{\circ} \mathrm{C}$, corresponds to a weight loss of about $12 \%$. This weight loss could be 447 associated to the formation of Hap in advanced crystallization stages and it can be attributed 448 to the phase transitions within hydroxyapatite crystals as was previously reported by Piccirillo 449 et al. [41]. A further thermal process for temperature up to $830{ }^{\circ} \mathrm{C}$, corresponding to a 450 negligible weight loss is assumed to be the result of gradual dehydroxylation of Hap powder by reaction 12 .

\section{Figure 11.}

\section{4. Conclusions}

454 In this study Hap powders, mostly constituted by nanoparticles, were obtained in a batch reactor from the treatment of concentrated alkaline $\mathrm{P}(\mathrm{V})$ effluents obtained in the regeneration of ion-exchange resins using a $\mathrm{Ca}(\mathrm{II})$ solution.

457 Three stages were identified in the precipitation of phosphate as Hap for $\mathrm{pH}$ values ranging 458 from 8 to 11.5 : a) induction period, with a small decrease in phosphate concentration, b) homogeneous nucleation, with maintaining or even a little increase of phosphate concentration and c) further homogeneous nucleation, with a constant decrease of phosphate. 
461 A constant $\mathrm{pH}$ of 11.5 favored a higher precipitation rate of phosphate to form Hap when 462 compared with rate obtained for $\mathrm{pH} \mathrm{8,10}$ and also at variable $\mathrm{pH}$. However, the degree of 463 crystallinity was higher for lower $\mathrm{pH}$ values assessed in this study (namely, 8 and 10).

464 Higher initial $\mathrm{P}(\mathrm{V})$ concentration lead to the formation of Hap precipitate powders with higher degree of crystallinity and crystal diameter, but also lower mean particle size.

As $\mathrm{Ca}(\mathrm{II})$ dosing rate increased, phosphate precipitation rate was higher, also the mean size and degree of crystallinity of the prepared particles were increased. Furthermore, the stirring speed (between 50 and $250 \mathrm{rpm}$ ) not reported any significate effect on the phosphate precipitation rate.

470

\section{Acknowledgments}

This study has been supported by the ZERODISCHARGE project (CTQ2011-26799)

473 financed by Ministry of Science and Innovation (MINECO, Spain) and the Catalan 474 government (project ref. 2009SGR905).

\section{References}

[1] Z. Bradford-Hartke, P. Lant, G. Leslie, Phosphorus recovery from centralised municipal water recycling plants, Chem. Eng. Res. Des. 90 (2012) 78-85. doi:10.1016/j.cherd.2011.08.006.

[2] T. Nur, M.A.H. Johir, P. Loganathan, T. Nguyen, S. Vigneswaran, J. Kandasamy, Phosphate removal from water using an iron oxide impregnated strong base anion exchange resin, J. Ind. Eng. Chem. 20 (2014) 1301-1307. doi:10.1016/j.jiec.2013.07.009.

[3] V. Dhand, K.Y. Rhee, S.-J. Park, The facile and low temperature synthesis of nanophase hydroxyapatite crystals using wet chemistry., Mater. Sci. Eng. C. Mater. Biol. Appl. 36 (2014) 152-9. doi:10.1016/j.msec.2013.11.049.

[4] Y. Liu, X. Sheng, Y. Dong, Y. Ma, Removal of high-concentration phosphate by calcite: Effect of sulfate and pH, Desalination. 289 (2012) 66-71.

doi:10.1016/j.desal.2012.01.011. 
[5] M. Das Gupta, P. Loganathan, S. Vigneswaran, Adsorptive Removal of Nitrate and Phosphate from Water by a Purolite Ion Exchange Resin and Hydrous Ferric Oxide Columns in Series, Sep. Sci. Technol. 47 (2012) 1785-1792.

doi:10.1080/01496395.2012.658487.

[6] S. Sengupta, A. Pandit, Selective removal of phosphorus from wastewater combined with its recovery as a solid-phase fertilizer., Water Res. 45 (2011) 3318-30. doi:10.1016/j.watres.2011.03.044.

[7] A.T.K. Tran, Y. Zhang, D. De Corte, J.-B. Hannes, W. Ye, P. Mondal, et al., Precovery as calcium phosphate from wastewater using an integrated selectrodialysis/crystallization process, J. Clean. Prod. 77 (2014) 140-151. doi:10.1016/j.jclepro.2014.01.069.

[8] I. Katz, C.G. Dosoretz, Desalination of domestic wastewater effluents: phosphate removal as pretreatment, Desalination. 222 (2008) 230-242. doi:10.1016/j.desal.2007.01.160.

[9] O.A. Diaz, K.R. Reodyit, P.A.M. Jr, Solubility of inorganic phosphorous in stream water as influenced by $\mathrm{pH}$ and calcium concentration , 28 (1994) 1755-1763.

[10] F. Lagno, S.D.F. Rocha, L. Katsarou, G.P. Demopoulos, Supersaturation-Controlled Synthesis of Dicalcium Phosphate Dihydrate and Nanocrystalline Calcium-De fi cient Hydroxyapatite, (2012).

[11] D.K. and P.G.K. N. Spanos, A. Patis, Precipitation of calcium phosphate from simulated milk ultrafiltrate solutions, Cryst. Growth Des. 2007.7 (2007) 25-29.

[12] L. Wang, G.H. Nancollas, Calcium orthophosphates: crystallization and dissolution., Chem. Rev. 108 (2008) 4628-69. doi:10.1021/cr0782574.

[13] J.C. Elliott, Structure and Chemistry of the Apatites and Other Calcium Orthophosphates, 18 (1994).

[14] O.S.L. Bruisma, G.M.Vanrosmalen, M.M.Seckler, Phosphate removal in a fluidized bed -I. Identification of physical processes, Wat.Res. 5 (1996) 1585-1588.

[15] L. Boskey, S. Posner, Formation of Hydroxyapatite at Low Supersaturation, I (1974) 40-45.

[16] C. Liu, Y. Huang, W. Shen, J. Cui, Kinetics of hydroxyapatite precipitation at pH 10 to 11., Biomaterials. 22 (2001) 301-6. http://www.ncbi.nlm.nih.gov/pubmed/19362524.

[17] F. Castro, A. Ferreira, F. Rocha, A. Vicente, J. António Teixeira, Characterization of intermediate stages in the precipitation of hydroxyapatite at $37^{\circ} \mathrm{C}$, Chem. Eng. Sci. 77 (2012) 150-156. doi:10.1016/j.ces.2012.01.058.

[18] L.-W. Du, S. Bian, B.-D. Gou, Y. Jiang, J. Huang, Y.-X. Gao, et al., Structure of Clusters and Formation of Amorphous Calcium Phosphate and Hydroxyapatite: From 
the Perspective of Coordination Chemistry, Cryst. Growth Des. 13 (2013) 3103-3109. doi:10.1021/cg400498j.

[19] M.B.Tomson. and. P. Koutsoukos, Z.Amjad,et al., Calcium Phosphates. A Constant Composition Study, J. Am. Chem. Soc. (1980) 1553-1557.

[20] F. Castro, F. Rocha, J. Anto, Continuous-Flow Precipitation of Hydroxyapatite at $37^{\circ}$ $\mathrm{C}$ in a Meso Oscillatory Flow Reactor, (2013).

[21] S.K. Ghosh, S.K. Roy, B. Kundu, S. Datta, D. Basu, Synthesis of nano-sized hydroxyapatite powders through solution combustion route under different reaction conditions, Mater. Sci. Eng. B. 176 (2011) 14-21. doi:10.1016/j.mseb.2010.08.006.

[22] T.T.T. Pham, T.P. Nguyen, T.N. Pham, T.P. Vu, D.L. Tran, H. Thai, et al., Impact of physical and chemical parameters on the hydroxyapatite nanopowder synthesized by chemical precipitation method, Adv. Nat. Sci. Nanosci. Nanotechnol. 4 (2013) 035014. doi:10.1088/2043-6262/4/3/035014.

[23] I. Puigdomènech, Inorganic Chemistry Department, Inorganic Chemistry Department, Chemical Equilibrium Software Hydra and Medusa, Stock. Sweden. (2001).

[24] G.S. Han, S. Lee, D.W. Kim, D.H. Kim, J.H. Noh, J.H. Park, et al., A Simple Method To Control Morphology of Hydroxyapatite Nano- and Microcrystals by Altering Phase Transition Route, Cryst. Growth Des. 13 (2013) 3414-3418. doi:10.1021/cg400308a.

[25] J.O.Nriagu. And, P.B. Moore, Phosphate Minerals, Springer-Veriag. (1984).

[26] D.A. Skoog and D.M.West., Fundamental of Analytical Chemistry,, (1976) 3th Edition. Saunders Colleg.

[27] E.C. Moreno, K. Varughese, crystal growth of calcium apatite from dilute solutions degree of supersaturation on initial precipitation rates, 53 (1981) 20-30.

[28] W.P. Inskeep, J.C. Silvertooth, Kinetjcs of hydroxyapatite precipitation at $\mathrm{pH} 7.4$ to 8 $.4 *,(1988) 1883-1893$.

[29] B. Xie, T.J. Halter, B.M. Borah, G.H. Nancollas, Tracking Amorphous Precursor Formation and Transformation during Induction Stages of Nucleation, Cryst. Growth Des. (2014).

[30] S. Koutsopoulos, Synthesis and characterization of hydroxyapatite crystals: a review study on the analytical methods., J. Biomed. Mater. Res. 62 (2002) 600-12. doi:10.1002/jbm.10280.

[31] A. Paz, D. Guadarrama, M. Lopez, Jesus E. Gonzales, N. Brizuela and J.Aragón, a comparative study of hydroxyapatite nanoparticles synthesized by different routes, Quim. Nov. 35 (2012) 1724-1727.

[32] I. Sporysh, E. Shynkaruk, O. Lysko, A. Shynkaruk, V. Dubok, E. Buzaneva, et al., Biomimetic hydroxyapatite nanocrystals in composites with C60 and Au-DNA 
nanoparticles: IR-spectral study, Mater. Sci. Eng. B. 169 (2010) 128-133. doi:10.1016/j.mseb.2009.10.039.

[33] F. Castro, S. Kuhn, K. Jensen, A. Ferreira, F. Rocha, A. Vicente, et al., Process intensification and optimization for hydroxyapatite nanoparticles production, Chem. Eng. Sci. 100 (2013) 352-359. doi:10.1016/j.ces.2013.01.002.

[34] E. Landi, G. Celotti, G. Logroscino, a. Tampieri, Carbonated hydroxyapatite as bone substitute, J. Eur. Ceram. Soc. 23 (2003) 2931-2937. doi:10.1016/S09552219(03)00304-2.

[35] F. A. Müller, L. Müller, D. Caillard, E. Conforto, Preferred growth orientation of biomimetic apatite crystals, J. Cryst. Growth. 304 (2007) 464-471.

doi:10.1016/j.jcrysgro.2007.03.014.

[36] R. Rodriguez.-Clemente. J. Gomez-Morales, J.Torrent-Burgues, Crystal Size Distribution of Hydroxyapatite Precipitated in a MSMPR Reactor, (2001) 1065-1074.

[37] Q. Yang, J.-X. Wang, L. Shao, Q.-A. Wang, F. Guo, J.-F. Chen, et al., High Throughput Methodology for Continuous Preparation of Hydroxyapatite Nanoparticles in a Microporous Tube-in-Tube Microchannel Reactor, Ind. Eng. Chem. Res. 49 (2010) 140-147. doi:10.1021/ie9005436.

[38] M. Kucher, D. Babic, M. Kind, Precipitation of barium sulfate: Experimental investigation about the influence of supersaturation and free lattice ion ratio on particle formation, Chem. Eng. Process. Process Intensif. 45 (2006) 900-907. doi:10.1016/j.cep.2005.12.006.

[39] J. A. Dirksen, T. A. Ring, Fundamentals of crystallization: Kinetic effects on particle size distributions and morphology, Chem. Eng. Sci. 46 (1991) 2389-2427. doi:10.1016/0009-2509(91)80035-W.

[40] D. Bernache-assollant, A. Ababou, E. Champion, M. Heughebaert, Sintering of calcium phosphate hydroxyapatite $\mathrm{Ca}_{10}\left(\mathrm{PO}_{4}\right)_{6}(\mathrm{OH})_{2} \mathrm{I}$. Calcination and particle growth, 23 (2003) 229-241.

[41] C. Piccirillo, M.F. Silva, R.C. Pullar, I. Braga da Cruz, R. Jorge, M.M.E. Pintado, et al., Extraction and characterisation of apatite- and tricalcium phosphate-based materials from cod fish bones, Mater. Sci. Eng. C. 33 (2013) 103-110. doi:10.1016/j.msec.2012.08.014. 


\begin{tabular}{|c|c|}
\hline Species/solid formation reaction & $\log \mathrm{K}$ \\
\hline $2 \mathrm{H}^{+}+\mathrm{PO}_{4}^{3-}+\mathrm{Ca}^{2+} \leftrightarrow \mathrm{CaH}_{2} \mathrm{PO}_{4}^{+}$ & 21.0 \\
\hline $\mathrm{H}^{+}+\mathrm{PO}_{4}^{3-}+\mathrm{Ca}^{2+} \leftrightarrow \mathrm{CaH}_{2} \mathrm{PO}_{4}$ & 15.1 \\
\hline $\mathrm{H}_{2} \mathrm{O}+\mathrm{Ca}^{2+} \leftrightarrow \mathrm{CaOH}^{+}+\mathrm{H}^{+}$ & -12.8 \\
\hline $\mathrm{PO}_{4}^{3-}+\mathrm{Ca}^{2+} \leftrightarrow \mathrm{CaPO}_{4}^{-}$ & 6.5 \\
\hline $2 \mathrm{H}^{+}+\mathrm{PO}_{4}^{3-} \leftrightarrow \mathrm{H}_{2} \mathrm{PO}_{4}^{-}$ & 19.6 \\
\hline $3 \mathrm{H}^{+}+\mathrm{PO}_{4}^{3-} \leftrightarrow \mathrm{H}_{3} \mathrm{PO}_{4}$ & $\begin{array}{l}21.7 \\
12.4\end{array}$ \\
\hline $\mathrm{H}^{+}+\mathrm{PO}_{4}^{3-} \leftrightarrow \mathrm{HPO}_{4}^{2-}$ & $\begin{array}{l}12.4 \\
39.1\end{array}$ \\
\hline $4 \mathrm{H}^{+}+2 \mathrm{PO}_{4}^{3-}+\mathrm{Ca}^{2+} \leftrightarrow \mathrm{Ca}\left(\mathrm{H}_{2} \mathrm{PO}_{4}\right)_{2}$ & -22.8 \\
\hline $2 \mathrm{H}_{2} \mathrm{O}+\mathrm{Ca}^{2+} \leftrightarrow \mathrm{Ca}(\mathrm{OH})_{2}+2 \mathrm{H}^{+}$ & 28.9 \\
\hline $2 \mathrm{PO}_{4}^{3-}+3 \mathrm{Ca}^{2+} \leftrightarrow \mathrm{Ca}_{3}\left(\mathrm{PO}_{4}\right)_{2}$ & 46.9 \\
\hline $\mathrm{H}^{+}+3 \mathrm{PO}_{4}^{3-}+4 \mathrm{Ca}^{2+} \leftrightarrow \mathrm{Ca}_{4} \mathrm{H}^{3}\left(\mathrm{PO}_{4}\right)_{3}$ & 40.5 \\
\hline $3 \mathrm{PO}_{4}^{3-}+4 \mathrm{Ca}^{2+}+\mathrm{H}_{2} \mathrm{O} \leftrightarrow \mathrm{Ca}_{5}\left(\mathrm{PO}_{4}\right)_{3} \mathrm{OH}+\mathrm{H}^{+}$ & 19.0 \\
\hline $\begin{array}{l}\mathrm{H}^{+}+\mathrm{PO}_{4}^{3-}+\mathrm{Ca}^{2+} \leftrightarrow \mathrm{CaHPO}_{4} \cdot 2 \mathrm{H}_{2} \mathrm{O} \\
\mathrm{Ca}^{2+}+\mathrm{H}_{2} \mathrm{O} \leftrightarrow \mathrm{CaO}+2 \mathrm{H}^{+}\end{array}$ & -32.8 \\
\hline
\end{tabular}

Table 1. Formation constants $\mathrm{K}$ (in $\log$ value) of the main aqueous and mineral phases involved in the system $\mathrm{CaCl}_{2}-\mathrm{NaH}_{2} \mathrm{PO}_{4}-\mathrm{H}_{2} \mathrm{O}$ from the HYDRA- Medusa data base [23]. 


\begin{tabular}{|c|c|c|c|}
\hline $\begin{array}{c}\mathrm{P}(\mathrm{V})_{\mathrm{i}} \\
(\mathrm{g} / \mathrm{L} ; \mathrm{mol} / \mathrm{L})\end{array}$ & $\begin{array}{c}{\left[\mathrm{Ca}^{2+}\right]} \\
(\text { Hydra-Medusa }) \\
(\mathrm{mol} / \mathrm{L})\end{array}$ & $\begin{array}{c}\text { Slope rate } \\
\mathrm{Ln} \mathrm{P}(\mathrm{V})-\mathrm{Ln} \mathrm{P}(\mathrm{V})_{0}= \\
\mathrm{f}(\mathrm{t})\end{array}$ & \\
\hline $1.0 ; 0.0105$ & 0.839 & $\mathrm{R}^{2}$ & \\
$0.5 ; 0.0052$ & 0.894 & $\mathrm{k}_{\mathrm{f}}=0.0014$ & 0.98 \\
$0.375 ; 0.0039$ & 0.908 & $\mathrm{k}_{\mathrm{f}}=0.0016$ & 0.84 \\
$0.250 ; 0.0026$ & 0.922 & $\mathrm{k}_{\mathrm{f}}=0.0031$ & 0.96 \\
$\mathrm{k}_{\mathrm{f}}=0.0041$ & 0.98 \\
\hline
\end{tabular}

Table 2. Initial experimental condition and linear regression parameters of $\ln \left[\mathrm{P}(\mathrm{V}) / \mathrm{P}(\mathrm{V})_{0}\right]$ as a function of time. 


\begin{tabular}{|c|c|c|c|c|c|c|c|}
\hline Test number & $\mathrm{FWHM}_{002}$ & $\begin{array}{l}\text { hkl }(002) \\
2 \theta\left({ }^{\circ}\right)\end{array}$ & $\begin{array}{l}\text { hkl (211) } \\
2 \theta\left(^{\circ}\right)\end{array}$ & $\begin{array}{l}\text { hkl (112) } \\
2 \theta\left(^{\circ}\right)\end{array}$ & $\begin{array}{l}\text { hkl (202) } \\
2 \theta\left(^{\circ}\right)\end{array}$ & $\begin{array}{l}\text { hkl (310) } \\
2 \theta\left(^{\circ}\right)\end{array}$ & $\begin{array}{c}\text { hkl (222) } \\
2 \theta\left(^{\circ}\right)\end{array}$ \\
\hline 1 & 0.329 & 26.14 & 31.86 & 32.38 & 34.21 & 40.06 & 46.9 \\
\hline 2 & 0.370 & 26.18 & 31.87 & 32.39 & 34.21 & 40.06 & 46.87 \\
\hline 3 & 0.268 & 26.13 & 31.87 & 32.19 & 34.16 & 39.80 & 47.11 \\
\hline 4 & 0.272 & 25.89 & 31.87 & 32.06 & 33.94 & 39.71 & 46.73 \\
\hline 5 & 0.383 & 26.13 & 31.86 & 32.25 & 33.84 & 39.89 & 46.98 \\
\hline 6 & 0.586 & 26.10 & 31.87 & 32.20 & - & 39.66 & 46.95 \\
\hline 7 & 0.667 & 26.25 & 31.87 & 32.43 & 34.15 & 38.95 & 45.77 \\
\hline 8 & 0.255 & 25.87 & 31.85 & 32.20 & 34.31 & 39.93 & 46.90 \\
\hline 9 & 0.401 & 26.14 & 30.66 & - & 34.15 & 39.61 & 47.00 \\
\hline 10 & 0.340 & 25.98 & 31.92 & 32.10 & 33.87 & 39.70 & 46.81 \\
\hline 11 & 0.302 & 25.80 & 31.86 & 32.17 & - & 39.72 & 46.87 \\
\hline $\begin{array}{l}\text { Powder diffraction File } \\
\text { 00-009-0432 } \\
\text { (Hap reference) }\end{array}$ & $\begin{array}{l}\text { Relative intensities } \\
\qquad 2 \theta\left(^{\circ}\right)\end{array}$ & $\begin{array}{c}40 \\
25.87\end{array}$ & $\begin{array}{c}100 \\
31.87\end{array}$ & $\begin{array}{c}60 \\
32.19\end{array}$ & $\begin{array}{c}25 \\
34.04\end{array}$ & $\begin{array}{c}20 \\
39.81\end{array}$ & $\begin{array}{c}30 \\
46.71\end{array}$ \\
\hline
\end{tabular}

(- ) No peak present

Table 3. The full-width at half-maximum (FWHM) and Miller Index (hkl) determined from XRD analysis for HAPs samples 


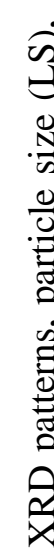

In

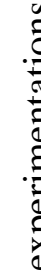

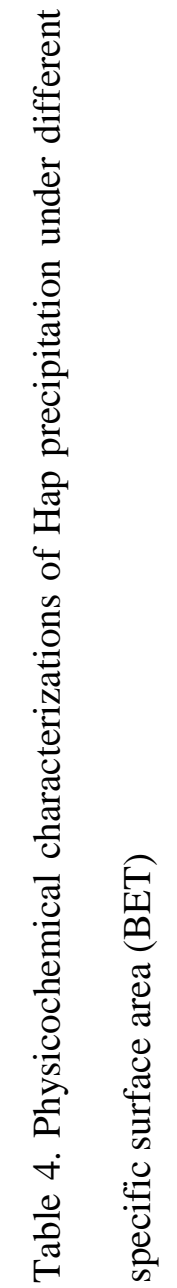

\begin{tabular}{|c|c|c|c|c|c|c|c|c|c|c|c|c|c|}
\hline & 気 & $\Xi$ & $\frac{0}{m}$ & $\frac{n}{N}$ & $\frac{b}{m}$ & $\begin{array}{l}\stackrel{0}{0} \\
\stackrel{N}{N}\end{array}$ & $\frac{0}{\sim}$ & व் & $\begin{array}{l}+ \\
\stackrel{\infty}{N}\end{array}$ & ?ִ & 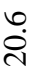 & $\begin{array}{l}m \\
m \\
m\end{array}$ & $\stackrel{+}{\stackrel{\sim}{\sim}}$ \\
\hline & $\widehat{\widehat{c}}$ & $\frac{\infty}{d}$ & $\hat{a}$ & $\begin{array}{l}n \\
\infty \\
\infty\end{array}$ & $\stackrel{n}{\text { m }}$ & $\sqrt{6}$ & ?̊: & $\stackrel{N}{N}$ & సర & ๙ু & $\frac{\infty}{a}$ & $\begin{array}{l}0 \\
\dot{n} \\
\dot{n}\end{array}$ & ๙ิ \\
\hline
\end{tabular}

\begin{tabular}{|c|c|c|c|c|c|c|c|c|c|c|c|c|c|c|}
\hline \multirow{2}{*}{ 约 } & 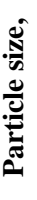 & 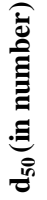 & ఏ & ב & $\begin{array}{l}0 \\
0 \\
0\end{array}$ & $\begin{array}{l}\stackrel{\infty}{0} \\
\stackrel{0}{0}\end{array}$ & $\ddot{\sigma}$ & $\stackrel{0}{0}$ & $\stackrel{m}{m}$ & $\stackrel{g}{\text { 巳े }}$ & $\stackrel{n}{n}$ & $\begin{array}{l}8 \\
0\end{array}$ & $\begin{array}{l}8 \\
\dot{0}\end{array}$ & $\stackrel{m}{\dot{m}}$ \\
\hline & 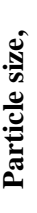 & 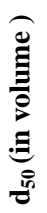 & ఏ & ڤึ & $\hat{\infty}^{\infty}$ & คุ & - & $\stackrel{?}{\stackrel{m}{\gamma}}$ & $\frac{n}{N}$ & $\underset{\infty}{\infty}$ & å & ๙े & $\stackrel{m}{\infty}$ & $\begin{array}{l}0 \\
\infty \\
\infty \\
n\end{array}$ \\
\hline
\end{tabular}

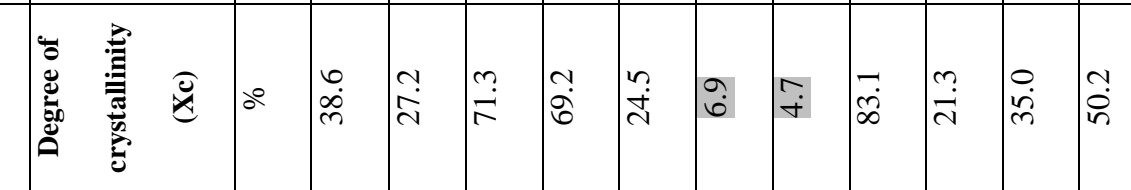

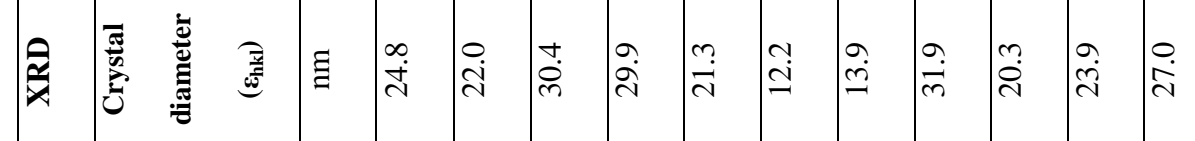

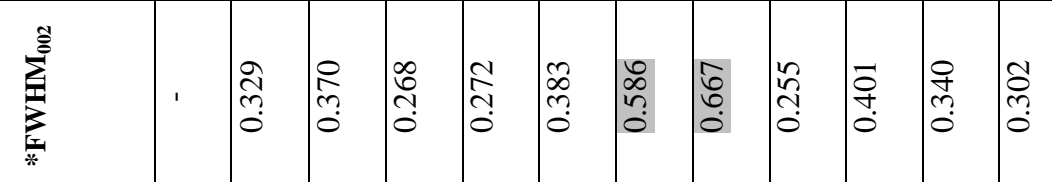

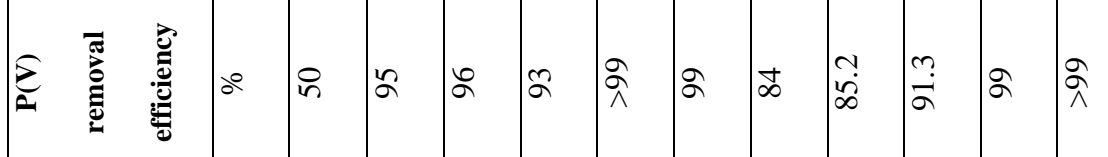

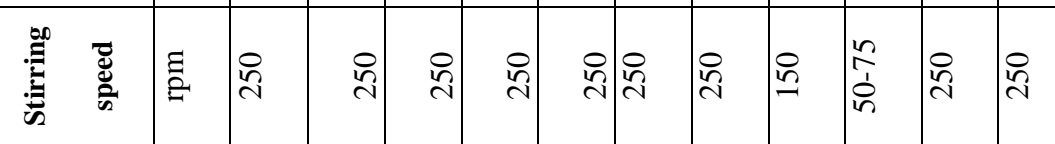

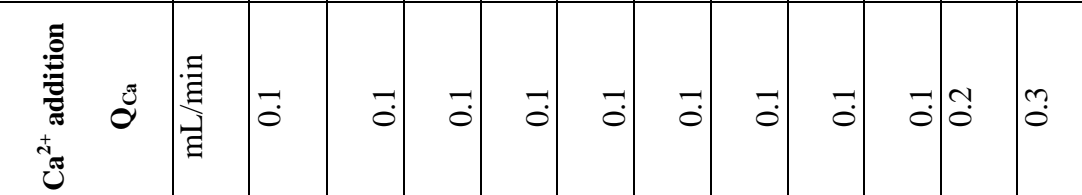

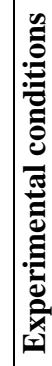

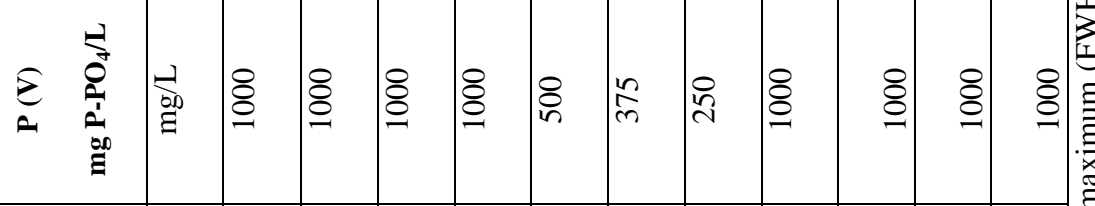

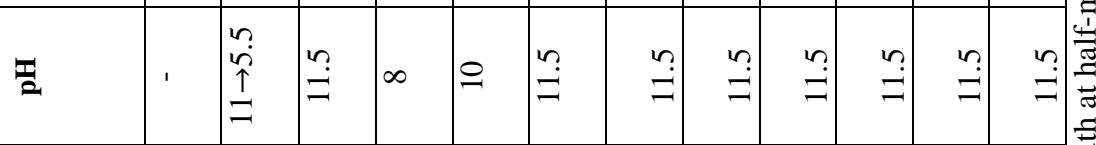

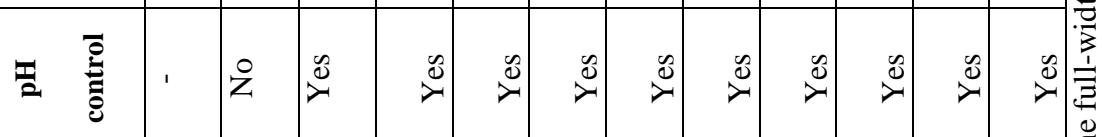

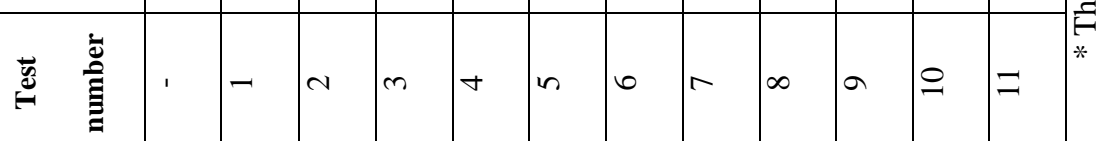




\section{Figure Captions:}

Figure 1. Experimental set up of the batch reactor for phosphate precipitation with calcium including a $\mathrm{CaCl}_{2}$ dosing pump, mechanical stirrer, the $\mathrm{NaOH}$ and $\mathrm{HCL}$ dosing pumps and the $\mathrm{pH}$ controller. Solids are removed at the bottom part of the reactor.

Figure 2. Species distribution diagram for the system $\mathrm{CaCl}_{2}-\mathrm{NaH}_{2} \mathrm{PO}_{4}-\mathrm{H}_{2} \mathrm{O}$ using the HYDRA-Medusa data base [23] under different $\mathrm{P}(\mathrm{V}) / \mathrm{Ca}(\mathrm{II})$ molar ratios: a) excess of $\mathrm{P}(\mathrm{V})$ over $\mathrm{Ca}(\mathrm{II})$ (molar ratio of 200 ), b) slightly excess of $\mathrm{P}(\mathrm{V})$ over $\mathrm{Ca}(\mathrm{II})$ (molar ratio of 10) and c) excess of $\mathrm{Ca}(\mathrm{II})$ over $\mathrm{P}(\mathrm{V})$ (molar ratio 0.5 ) for a total ionic strength of $0.5 \mathrm{M}$.

Figure 3. Evolution of a) phosphate and b) calcium concentration with time in Hap precipitation tests at constant $\mathrm{pH}(11.5)$ and variable $\mathrm{pH}$; c) phosphate recovery and $\mathrm{pH}$ evolution in variable $\mathrm{pH}$ experiment in the batch reactor.

Figure 4. a) The recovery and phosphate evolution profile and as a function of calcium concentration at constant $\mathrm{pH}$ values of 8,10 and 11.5 and b) detail of three crystallization stages in the batch reactor.

Figure 5. Influence of the initial phosphate concentration onto the Hap precipitation at $\mathrm{pH} 11.5$ as a function of total calcium concentration in the batch reactor for a) Phosphate concentration and b) calcium concentration.

Figure 6. Evolution of the $\ln \left[\mathrm{P}(\mathrm{V}) /\left(\mathrm{P}(\mathrm{V})_{0}\right]\right.$ as a function of time for the precipitation experiments at constant $\mathrm{pH}$ (11.5) for phosphate initial concentrations between 0.25 up to $1 \mathrm{~g} / \mathrm{L}$ using a batch reactor.

Figure 7. Influence of a) stirring speed and b) $\mathrm{Ca}$ (II) addition rate on phosphate concentration evolution as function of time during phosphate precipitation in a batch reactor. 
Figure 8. XRD analysis of the samples obtained in phosphate precipitation experiments for a) precipitation tests at constant and variable $\mathrm{pH}$ and b) precipitation tests under different initial phosphate concentration.

Figure 9. Particle size distribution in a) volume and b) number of Hap obtained from phosphate precipitation test at constant and variable $\mathrm{pH}$ and c) volume and d) number of Hap obtained from phosphate precipitation test at different initial phosphate concentration.

Figure 10. FE-SEM of Hap samples obtained from phosphate precipitation at constant

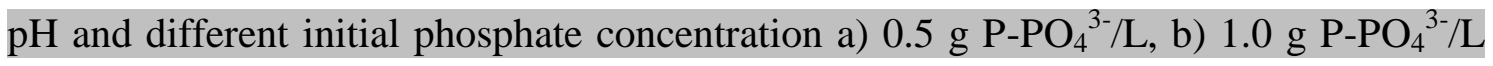

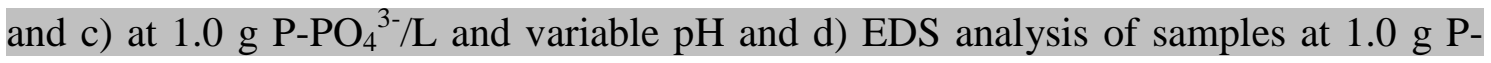
$\mathrm{PO}_{4}{ }^{3-} / \mathrm{L}$ and constant $\mathrm{pH}$.

Figure 11. Thermogravimetric Analysis (TGA) and Differential Thermal Analysis (DTA) of Hap synthesized at different agitation speed reactor for a) experiment 2 (low degree of crystallinity) and b) experiment 8 (high degree of crystallinity). 


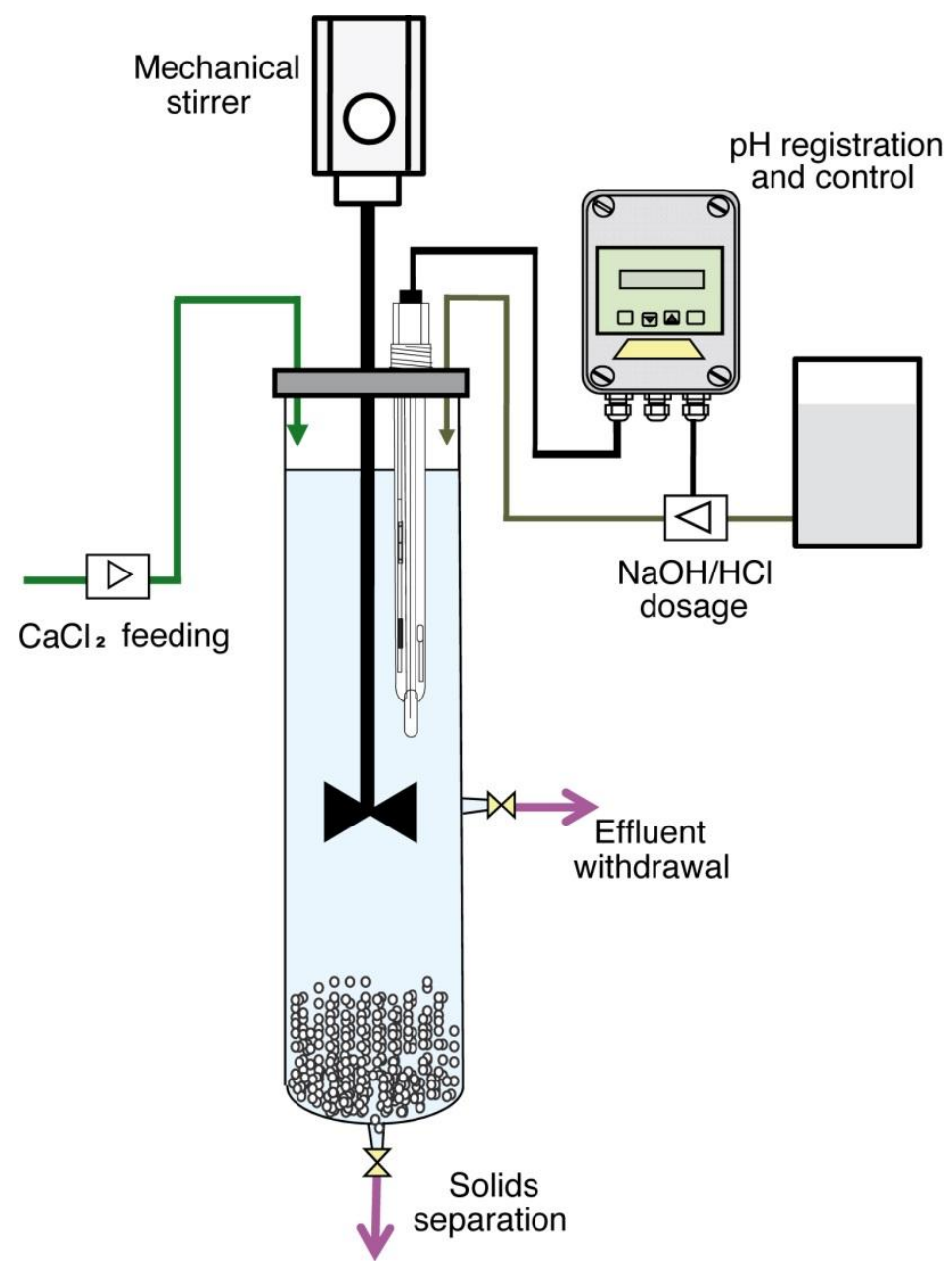

Figure 1. 


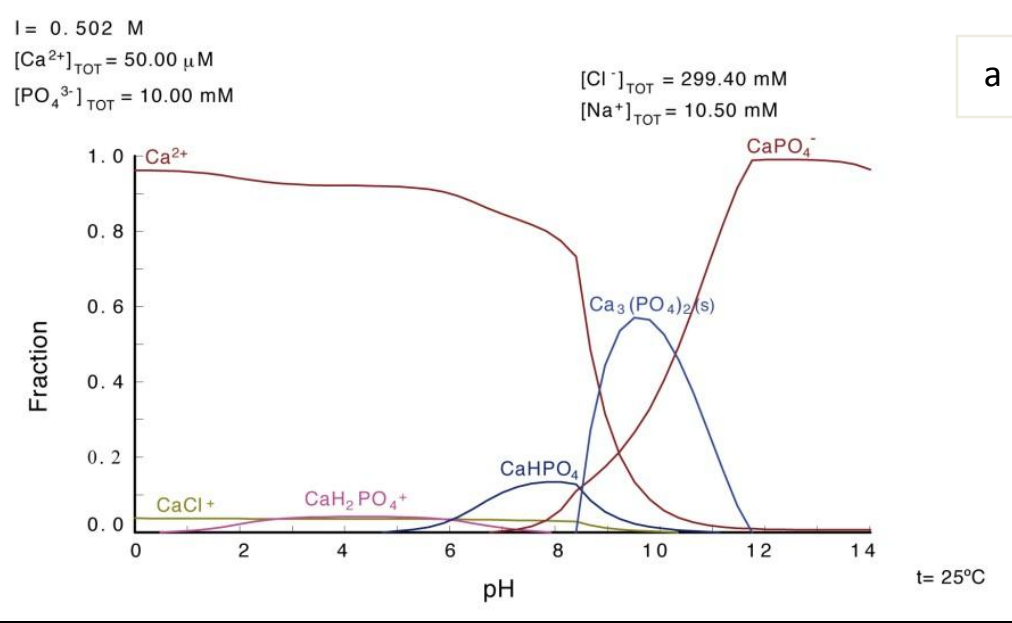

$\mathrm{I}=0.502 \mathrm{M}$
$\left[\mathrm{Ca}^{2+}\right]_{\mathrm{TT}}=1.00$

$\begin{array}{ll}{\left[\mathrm{Ca}^{2+}\right]_{\text {TOT }}=1.00 \mathrm{mM}} & {\left[\mathrm{Cl}^{-}\right]_{\text {TOT }}=299.40 \mathrm{mM}} \\ {\left[\mathrm{PO}_{4}{ }^{3-}\right]_{\text {TOT }}=10.00 \mathrm{mM}} & {\left[\mathrm{Na}^{+}\right]_{\text {TOT }}=10.50 \mathrm{mM}}\end{array}$

b
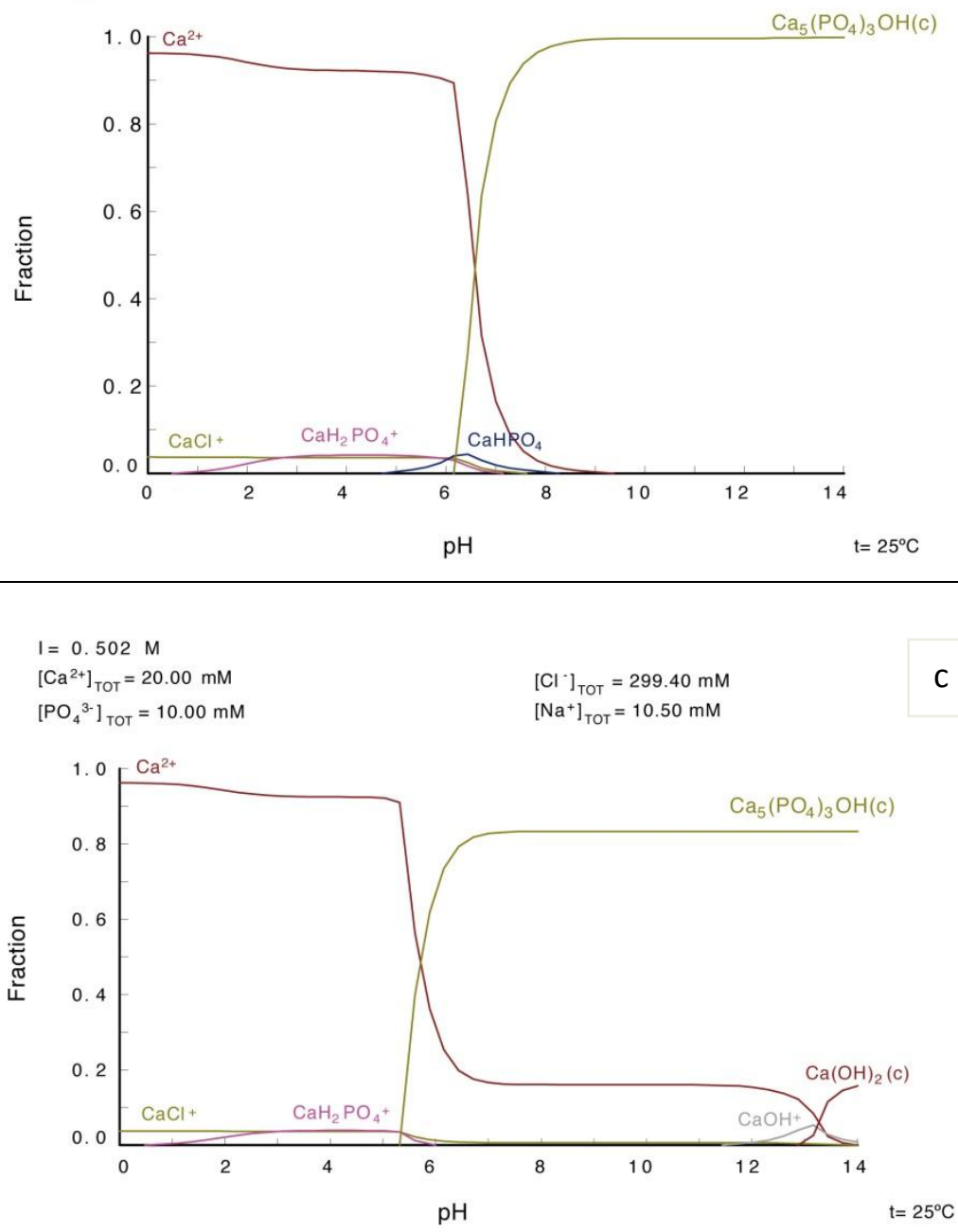

Figure 2. 

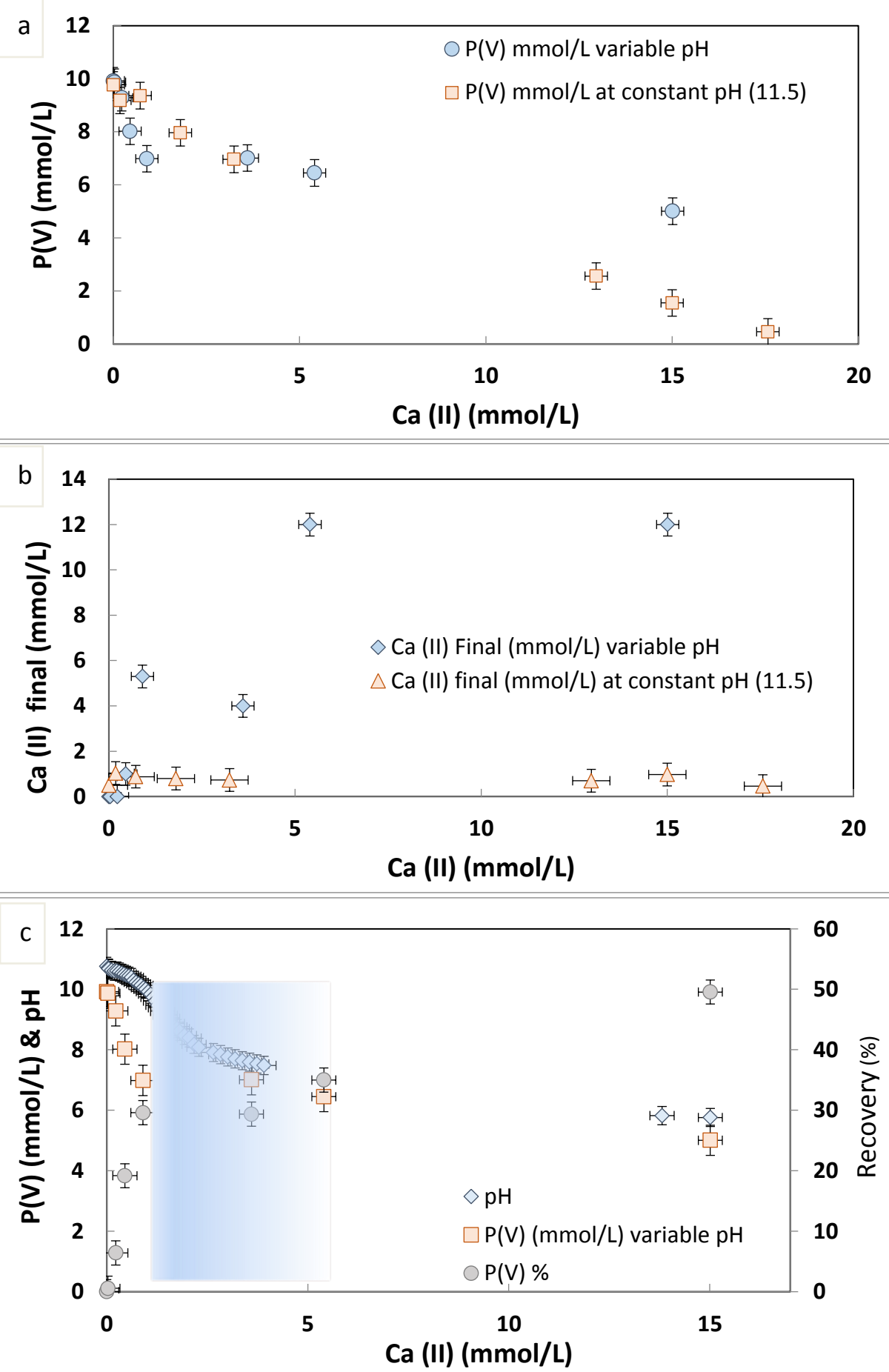

Figure 3. 

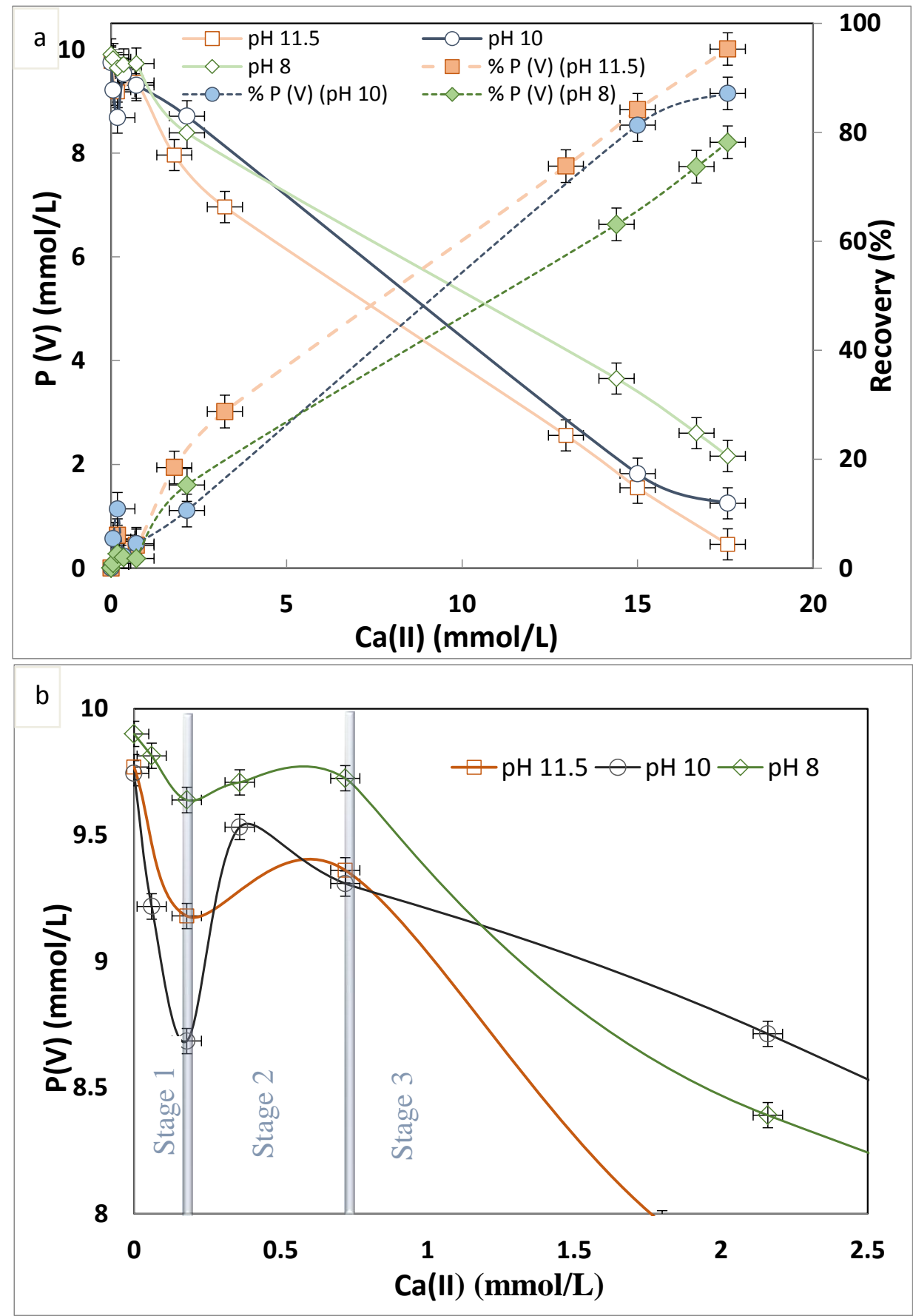

Figure 4. 


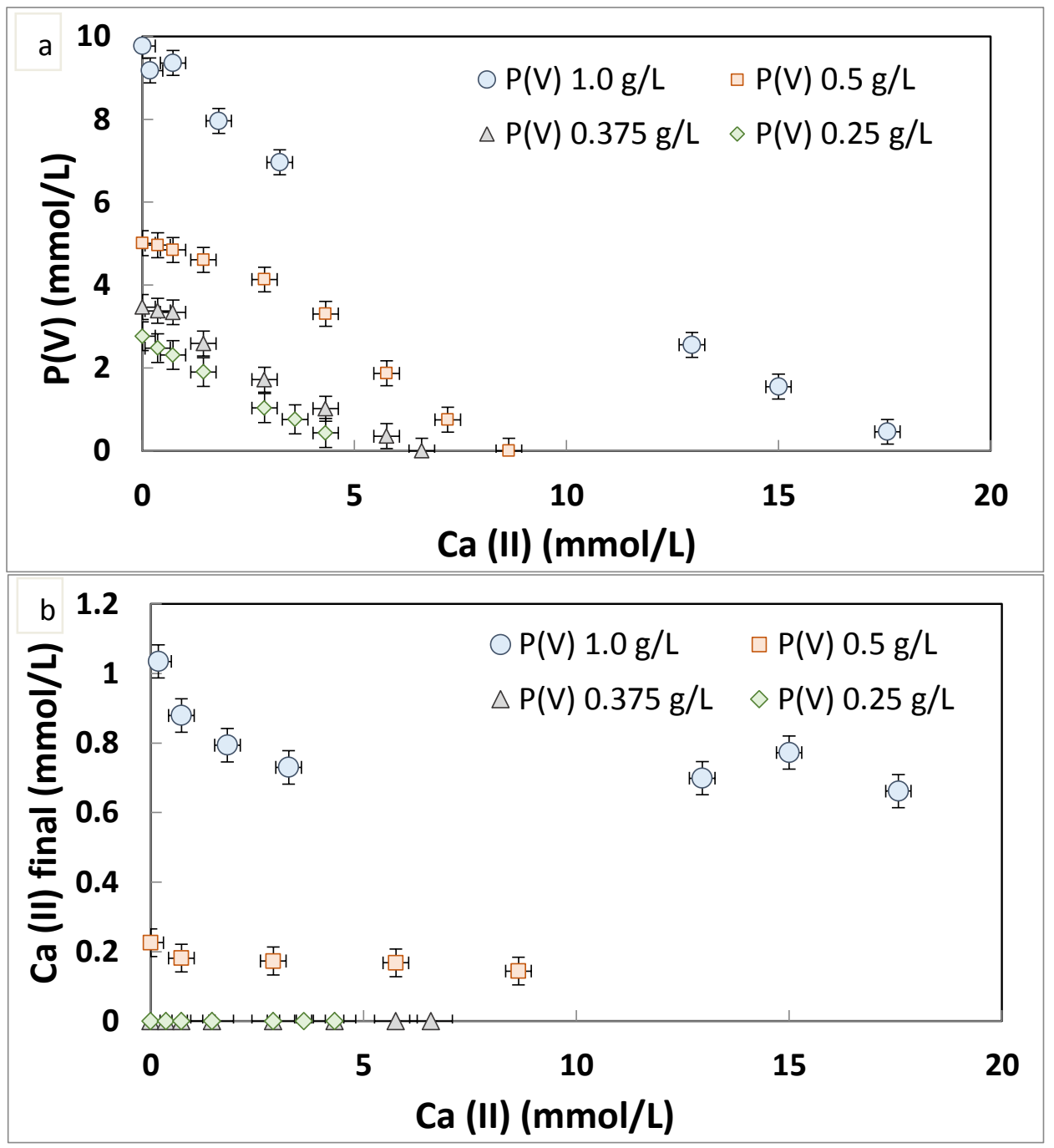

Figure 5. 


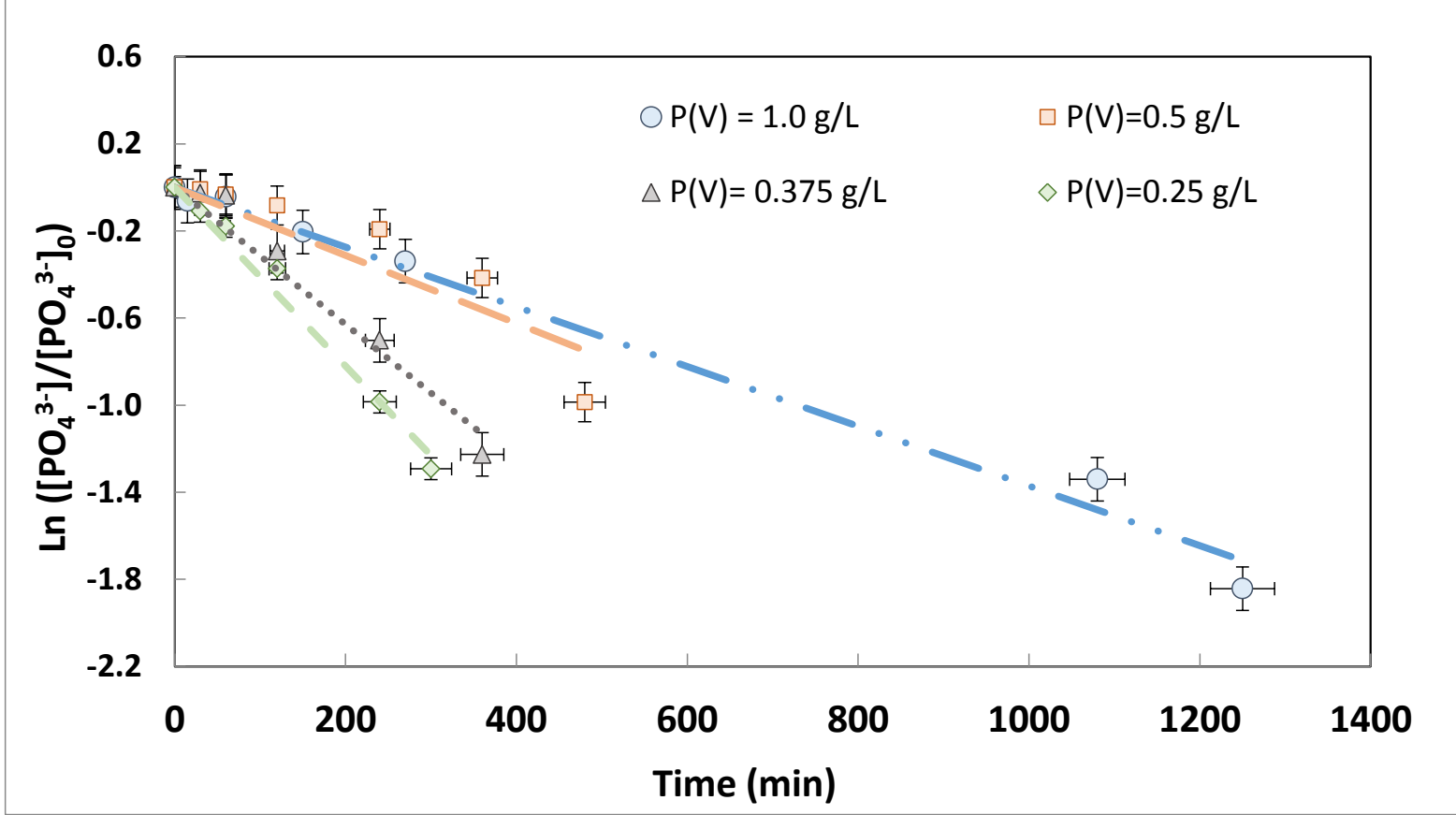

Figure 6. 


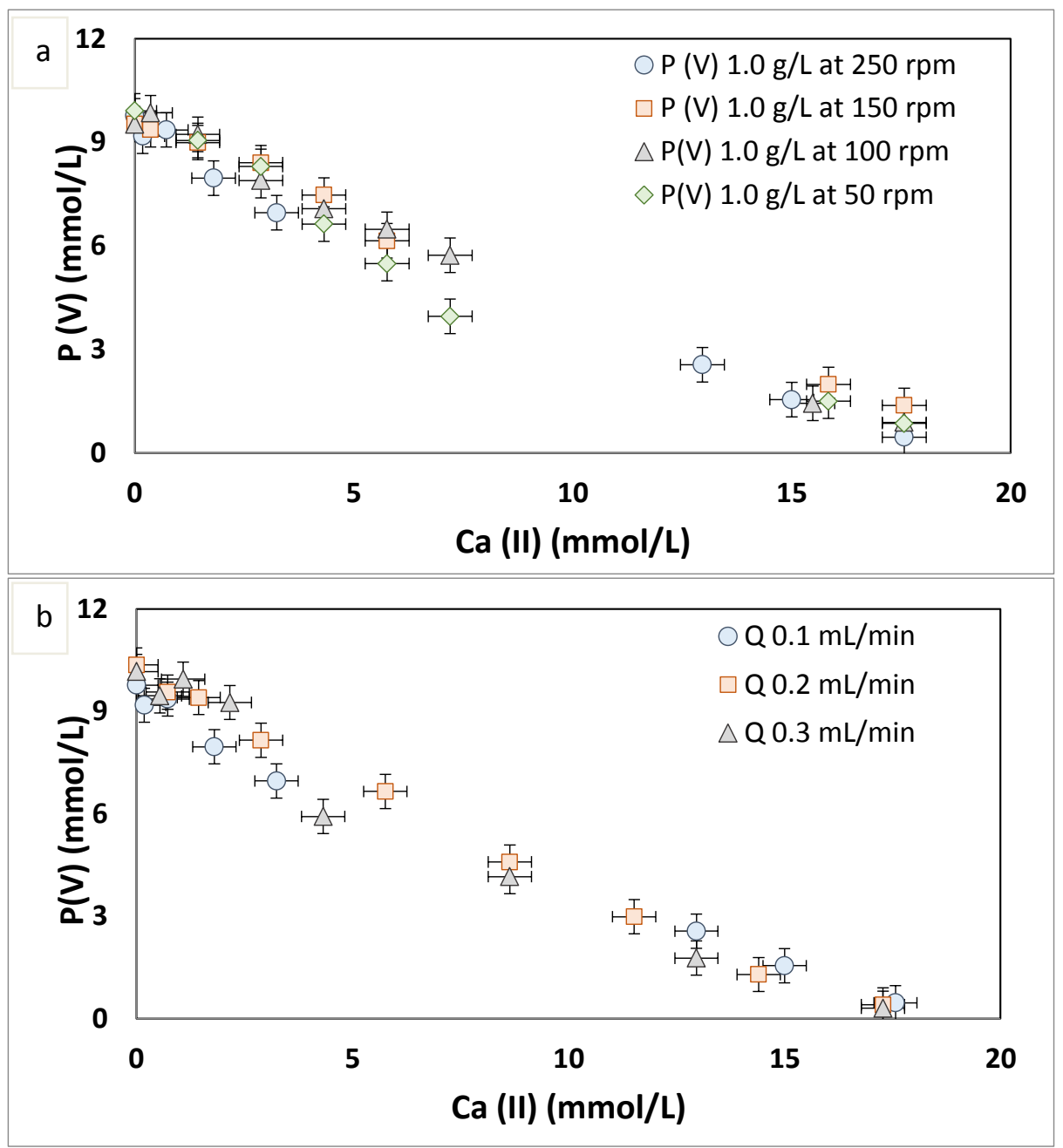

Figure 7. 


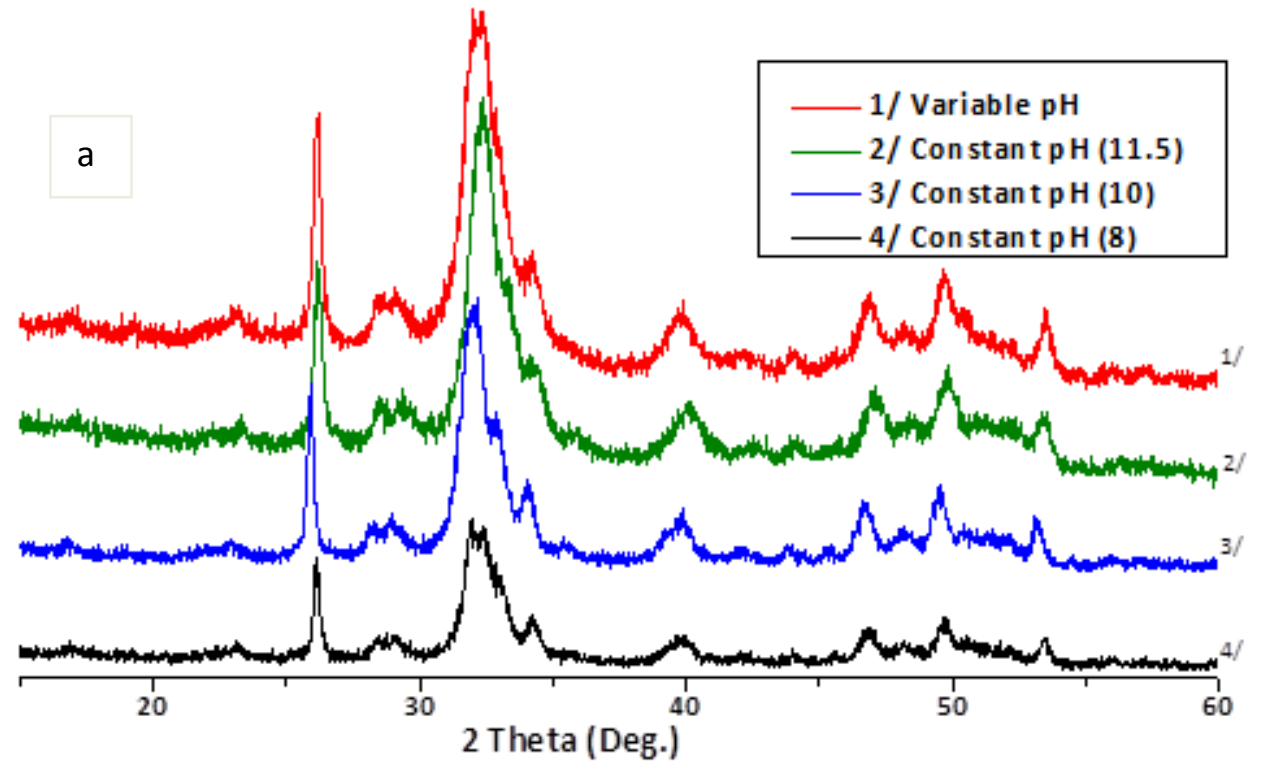

b

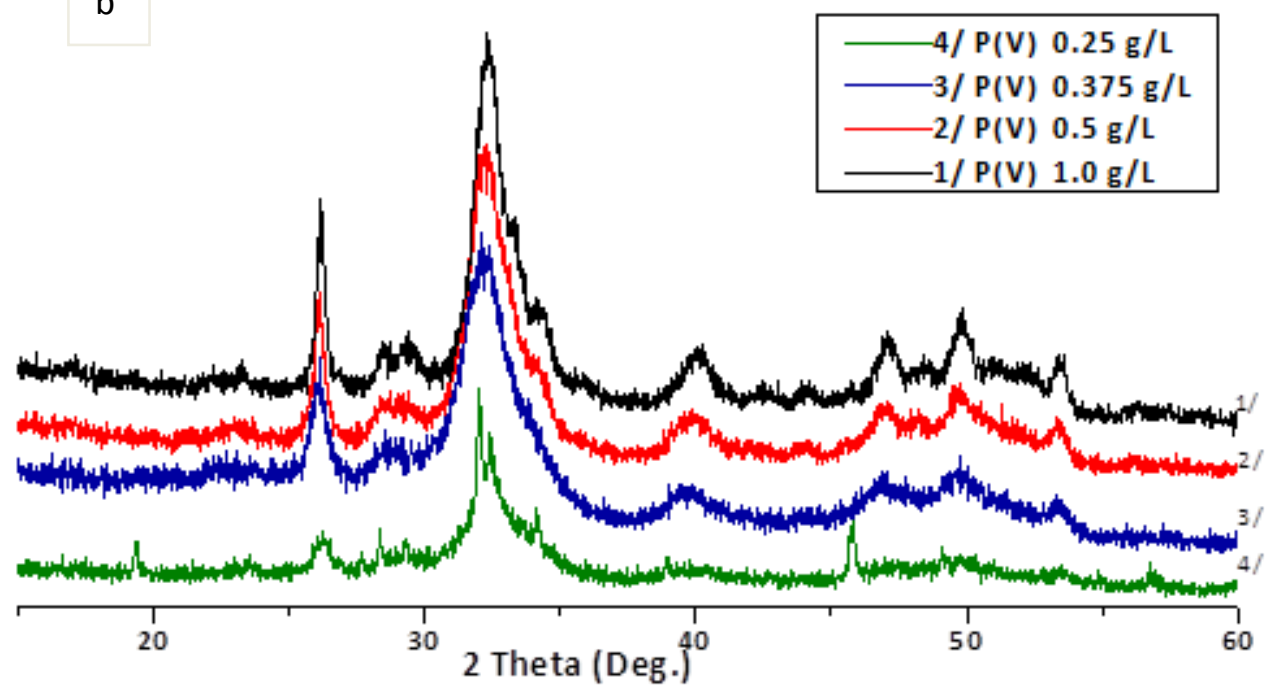

Figure 8. 


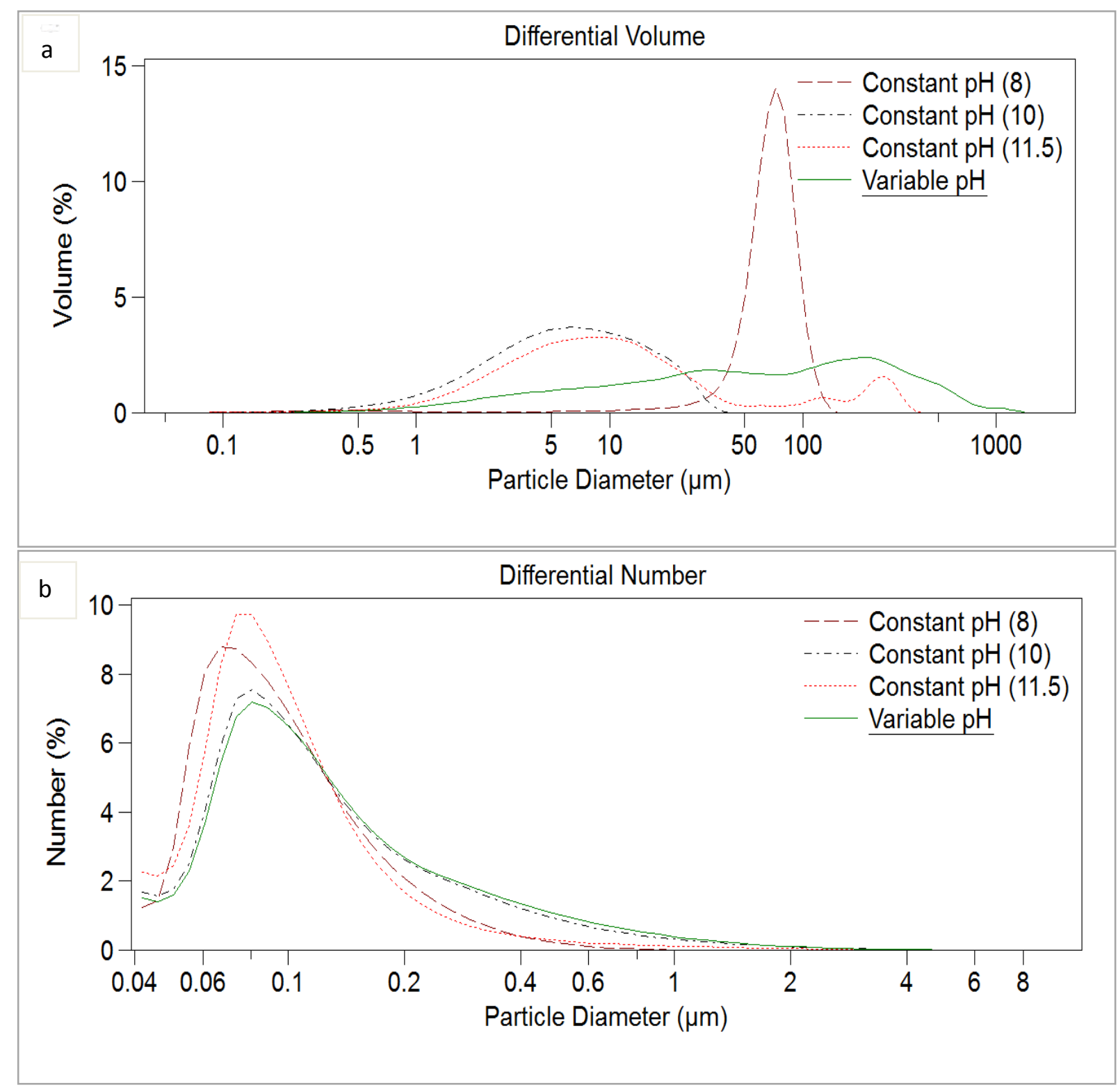




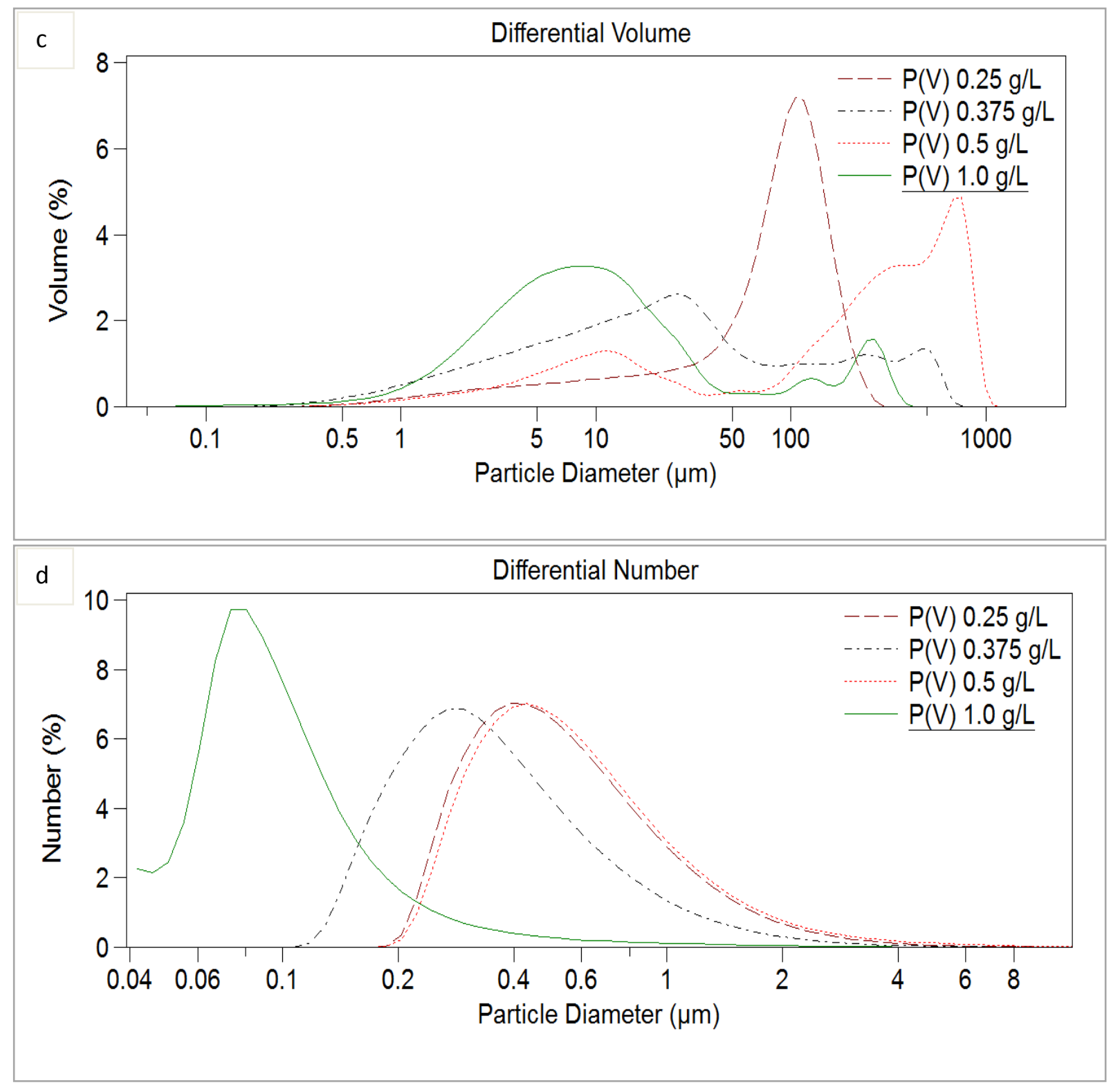

Figure 9. 

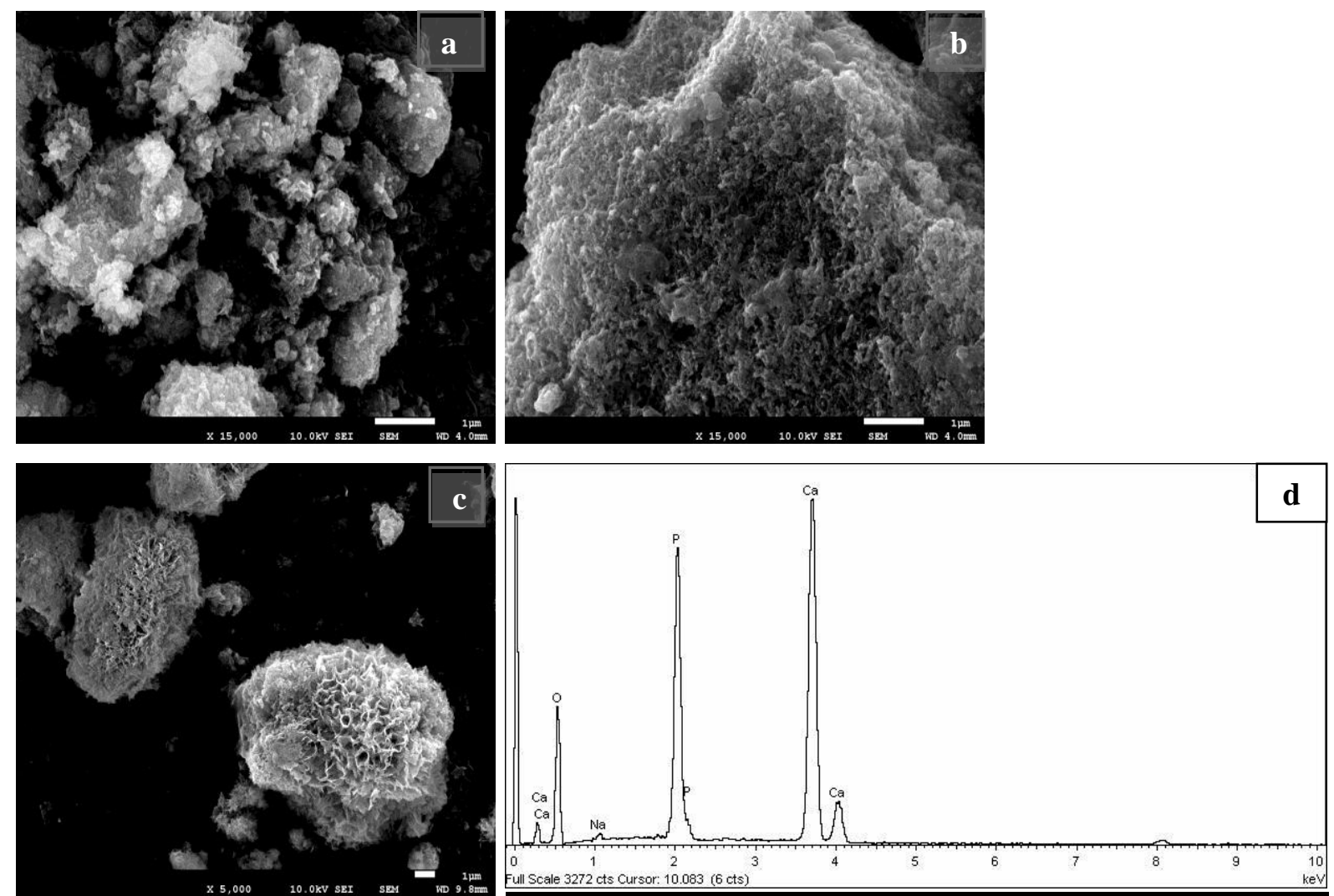

Figure 10. 


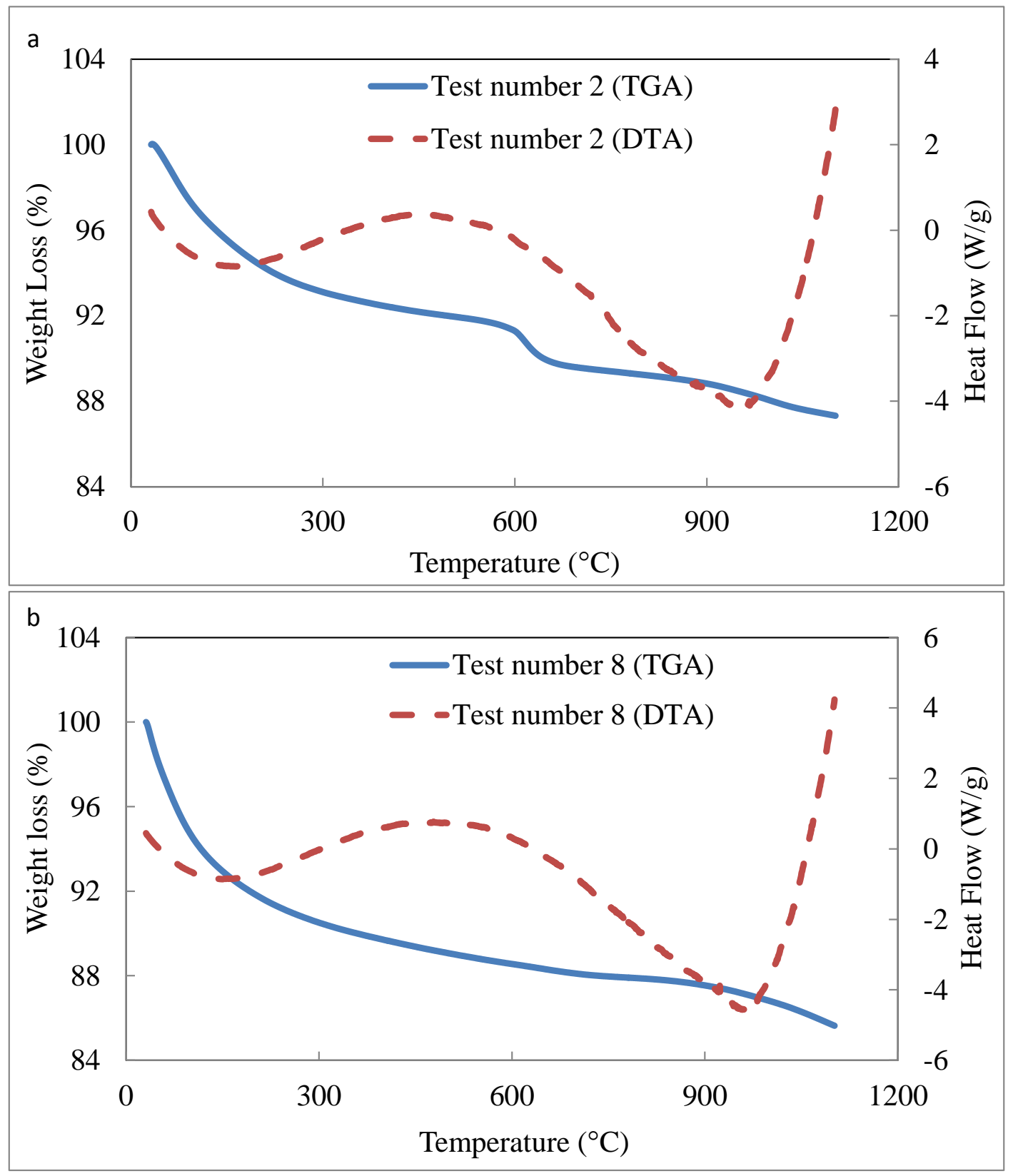

Figure 11. 